\title{
European Database of Carotenoid Levels in Foods. Factors Affecting Carotenoid Content
}

\author{
M. Graça Dias ${ }^{1}$, Grethe Iren A. Borge ${ }^{2}{ }^{\oplus}$, Kristina Kljak ${ }^{3}{ }^{\oplus}$, Anamarija I. Mandić ${ }^{4}$, Paula Mapelli-Brahm ${ }^{5} \oplus^{(0}$, \\ Begoña Olmedilla-Alonso ${ }^{6}{ }^{\circledR}$, Adela M. Pintea ${ }^{7}{ }^{\circledR}$, Francisco Ravasco ${ }^{1}{ }^{\mathbb{D}}$, Vesna Tumbas Šaponjac ${ }^{8}{ }^{\circledR}$, \\ Jolanta Sereikaite ${ }^{9}{ }^{\circledR}$, Liliana Vargas-Murga ${ }^{10} \oplus$, Jelena J. Vulić ${ }^{8}\left(\mathbb{D}\right.$ and Antonio J. Meléndez-Martínez ${ }^{5, *}$
}

Citation: Dias, M.G.; Borge, G.I.A. Kljak, K.; Mandić, A.I.;

Mapelli-Brahm, P.; Olmedilla-Alonso,

B.; Pintea, A.M.; Ravasco, F.; Tumbas

Šaponjac, V.; Sereikaitè, J.; et al.

European Database of Carotenoid

Levels in Foods. Factors Affecting Carotenoid Content. Foods 2021, 10, 912. https://doi.org/10.3390/ foods10050912

Academic Editor: Fani Mantzouridou and Stella Ordoudi

Received: 12 March 2021

Accepted: 14 April 2021

Published: 21 April 2021

Publisher's Note: MDPI stays neutral with regard to jurisdictional claims in published maps and institutional affiliations.

Copyright: (C) 2021 by the authors. Licensee MDPI, Basel, Switzerland. This article is an open access article distributed under the terms and conditions of the Creative Commons Attribution (CC BY) license (https:/ / creativecommons.org/licenses/by/ $4.0 /$ )
1 Food and Nutrition Department, National Institute of Health Doutor Ricardo Jorge, IP, Av. Padre Cruz, 1649-016 Lisboa, Portugal; m.graca.dias@insa.min-saude.pt (M.G.D.); francisco.ravasco@insa.min-saude.pt (F.R.)

2 Nofima AS, Norwegian Institute of Food, Fisheries and Aquaculture Research, NO 1433 Ås, Norway; grethe.iren.borge@nofima.no

3 Department of Animal Nutrition, Faculty of Agriculture, University of Zagreb, Svetošimunska Cesta 25, 10000 Zagreb, Croatia; kkljak@agr.hr

4 Institute of Food Technology in Novi Sad, University of Novi Sad, 21000 Novi Sad, Serbia; anamarija.mandic@fins.uns.ac.rs

5 Food Colour \& Quality Laboratory, Department of Nutrition \& Food Science, Facultad de Farmacia, Universidad de Sevilla, 41012 Sevilla, Spain; pmapelli@us.es

6 Institute of Food Science, Technology and Nutrition (ICTAN-CSIC), 28040 Madrid, Spain; bolmedilla@ictan.csic.es

7 Chemistry and Biochemistry Department, University of Agricultural Sciences and Veterinary Medicine, 400372 Cluj-Napoca, Romania; apintea@usamvcluj.ro

8 Faculty of Technology Novi Sad, University of Novi Sad, Bulevar cara Lazara 1, 21000 Novi Sad, Serbia; vesnat11@gmail.com (V.T.Š.); jvulic@uns.ac.rs (J.J.V.)

9 Department of Chemistry and Bioengineering, Vilnius Gediminas Technical University, 10223 Vilnius, Lithuania; jolanta.sereikaite@vgtu.lt

10 Biothani Europe S.L. Can Lleganya, 17451 Sant Feliu de Buixalleu, Spain; lsvargas@biothani.com

* Correspondence: ajmelendez@us.es

Abstract: Many studies indicate that diets including carotenoid-rich foods have positive effects on human health. Some of these compounds are precursors of the essential nutrient vitamin A. The present work is aimed at implementing a database of carotenoid contents of foods available in the European market. Factors affecting carotenoid content were also discussed. Analytical data available in peer-reviewed scientific literature from 1990 to 2018 and obtained by HPLC/UHPLC were considered. The database includes foods classified according to the FoodEx2 system and will benefit compilers, nutritionists and other professionals in areas related to food and human health. The results show the importance of food characterization to ensure its intercomparability, as large variations in carotenoid levels are observed between species and among varieties/cultivars/landraces. This highlights the significance of integrating nutritional criteria into agricultural choices and of promoting biodiversity. The uncertainty quantification associated with the measurements of the carotenoid content was very rarely evaluated in the literature consulted. According to the EuroFIR data quality evaluation system for food composition tables, the total data quality index mean was 24 in 35, reflecting efforts by researchers in the analytical methods, and less resources in the sampling plan documentation.

Keywords: agro-food; agronomy; food composition; fruits and vegetables

\section{Introduction}

The main dietary sources of carotenoids for humans are in general fruits and vegetables, although they are also present in other plant products (herbs, legumes, cereals or even oils), algae, animal foods, additives or supplements [1]. 
There are many studies indicating that carotenoid-rich diets can have a positive role in human health and contribute to reduce the risk of diseases associated with aging, such as certain cancers, cardiovascular disease, bone, skin or eye disorders and may be beneficial for mental and metabolic health, during pregnancy and early life. In addition to their role as colorants and bioactive compounds with possible positive effects on human health, some carotenoids also have a well-defined role as provitamin A nutrient, being key in combating vitamin A deficiency, especially in areas with low consumption of animal foods $[2,3]$.

However, neither the European Food Safety Authority (EFSA) [4] nor the U.S. Food and Nutrition Board [5] have established official recommended daily intakes/nutritional reference values for the main dietary carotenoids. Indeed, there is still insufficient categorical evidence of the amounts needed to help promote health, even for a widely studied non-provitamin A carotenoid such as lutein, which has been positively associated to eye health and other benefits [6,7].

According to the European labeling requirement [8], the daily reference intake for vitamin A is $800 \mu \mathrm{g}$, with 15\% (120 $\mu \mathrm{g})$ being considered significant to the label's nutritional table. The equivalence between carotenoids provitamin A and retinol is an issue on which a scientific consensus has not yet been established. According to the Food and Nutrition Board of the Institute of Medicine, in USA, for provitamin A carotenoids from food, $6 \mu \mathrm{g}$ of $\beta$-carotene or $12 \mu \mathrm{g}$ of $\alpha$-carotene or $12 \mu \mathrm{g}$ of $\beta$-cryptoxanthin are equivalent to $1 \mu \mathrm{g}$ of retinol. In terms of activity, twice those amounts are needed to obtain that of $1 \mu \mathrm{g}$ of retinol $[9,10]$. The first equivalence is named retinol equivalent (RE) and the second retinol activity equivalent (RAE). The Food and Agriculture Organization of the United Nations/International Network of Food Data Systems (FAO/INFOODS), adopted these equivalences with the note that they may be specific for each country [11]. The equivalence factors are estimated with large intervals of confidence due to factors that lead to high standard deviations, including large interindividual response, differences in food matrix and processing or analytical errors [12].

Apart from retinoids, carotenoids can also be enzymatically cleaved by humans into apocarotenoids and other derivatives, which are eliciting increasing interest, as they may be involved in biological actions. Given their versatility, carotenoids are importance continues growing in the era of sustainable healthy diets and for the development of innovative products such as novel foods or nutricosmetics, among others $[2,3,13]$.

The promotion of currently underutilized local foods is increasingly a priority to improve environmental sustainability and reducing in particular, the carbon footprint as local foods have been often replaced by processed unhealthy foods due to its convenience. Frequently, mainly in low-income countries, the latter foods are produced far from the place of consumption having negative impacts in health and the environment. According to FAO, in 2019, more than 6000 plant species have been cultivated for food. Of these less than 200 make major contributions to food production globally, regionally or nationally and only nine species account for $66 \%$ of total crop production [14]. In this context, food composition databases are important tools for the adequate choice of foods and to promote biodiversity by highlighting neglected yet nutritionally rich species that lost importance with growing industrialization.

Food composition data are used in different fields of knowledge, mainly in the areas of agro-food, nutrition and health [15]. They are often the basis of studies that link the ingestion of carotenoids with health outcomes, so the quality of the data is of particular importance. The uncertainty of these data influences that of studies made from those and their conclusions drastically. This is not positive not only in scientific terms but also in order to support the implementation of public health policies.

The determination of the different components of foodstuffs is particularly time consuming and expensive due to their diversity and the different analytical methods involved. Carotenoids are particularly difficult to analyze accurately due to their lipophilicity, instability, structural similarity or scarcity of certified reference materials, which poses problems of accuracy and comparability of results. On the other hand, there is a clear dispersion of 
food carotenoids composition data. In general, food composition databases only include $\beta$-carotene, the carotenoid with the highest theoretical vitamin A activity and probably the most ubiquitous in foods [1,2].

In general, variations in the profile of carotenoids within a species are not observed with the naked eye unless there are color mutants. However, great variations are perceived in each carotenoid content and in the total carotenoid content in the different varieties of a species. This variability requires high resources in the design and implementation of sampling plans and highly specialized analytical and human resources for obtaining high quality data.

Several original data quality assessment systems were developed by several entities, such as the United States Department of Agriculture (USDA), the Agence Française de Sécurite des Produits Alimentaires (AFSSA), the Bioactive Substances in Food Information Systems (BASIS), the Centro per lo Studio e la Prevenzione Oncologica (CSPO) and the German Food Code and Nutrient Data Base (BLS). More recently the European Food Information Resource (EuroFIR) developed a system based on those in order to harmonize food composition data evaluation, by compilers [16]. Although its importance and usefulness are indisputable it is still not widely. Regarding carotenoids the first works on data quality assessment dates back to 1993, although only the analytical steps were considered [17,18].

This work is aimed at developing a comprehensive database of analytical data on carotenoid contents in plant foods produced/marketed in Europe reported in peer reviewed primary scientific sources. The quality of the data was assessed following current EuroFIR AISBL (International Non-Profit Organization) recommendations for compilers [16]. On the other hand, factors influencing carotenoid levels in foods are discussed.

\section{Material and Methods}

\subsection{Data Collection}

The identification of the papers for data collection was done through the b-on (Online Knowledge Library), a search engine that pre index metadata in a single central index. It contains over 16,750 scientific international publications from 16 publishers, through subscriptions negotiated on a national (Portugal) basis with these publishers.

The following keywords were searched in titles: carotenoid OR carotene OR xanthophyll OR lutein OR zeaxanthin OR cryptoxanthin OR lycopene OR phytoene OR phytofluene. Thereafter filters related to European countries were applied: Albania OR Armenia OR Austria OR Azerbaijan OR Belarus OR Belgium OR Bosnia OR Bulgaria OR Croatia OR Cyprus OR Czech Republic OR Denmark OR Estonia OR Europe* OR Finland OR France OR Georgia OR Germany OR Greece OR Hungary OR Iceland OR Ireland OR Italy OR Kazakhstan OR Kosovo OR Latvia OR Liechtenstein OR Lithuania OR Luxembourg OR Macedonia OR Malta OR Moldova OR Monaco OR Montenegro OR Netherlands OR Norway OR Poland OR Portugal OR Romania OR Russia OR Serbia OR Slovakia OR Slovenia OR Spain OR Sweden OR Switzerland OR Turkey OR Ukraine OR United Kingdom OR UK were searched in all fields. From this search, using filters, papers containing Food OR Vegetable OR Fruit were selected. Papers about biological fluids and food of animal origin were excluded manually.

The research was conducted in papers published in the period 1990-2018 and only original research full-text papers were scrutinized. Only analytical data obtained by HPLC or UHPLC systems equipped with at least spectrophotometric detector were considered. The use or not of the saponification step during extraction method was registered since this step affects the analytical measurement results [1]. Only food items intended for human consumption produced and/or marketed in Europe were considered. Food supplements were not in the scope of this collection.

Each paper was analyzed by researchers working in the area of carotenoids, in particular with knowledge of the analytical methods. All carotenoids reported in each paper were collected and the water content, when available. References to carotenoids content expressed as RE, RAE and \% of the total, presented only in the graphic form and indicating 
only the minimum and maximum were discarded. The different units referred in the papers were converted to $\mu \mathrm{g} / 100 \mathrm{~g}$. The tables were organized to document the food, common name, scientific name including species and varieties/cultivars/landraces/accessions (whenever known). Other descriptors, including countries of origin and purchase, general food processing method, color and part analyzed, were also registered when available.

All foods items were classified according to the FoodEx2 hierarchical system developed by the European Food Safety Authority (EFSA), at least at level 1 (twenty food groups). When the number of foods at a given level was high, lower levels were used in order to distinguish them. That is, being a hierarchical system, when the group level comprised a large amount of foods (for instance, in the case of fruits and vegetables), the main sources of carotenoids, levels 3 and 4 were reached in order to obtain a greater distinction between the foods of these groups. Facet descriptors were used to provide additional information for processed foods.

\subsection{Data Quality Assessment}

The quality of data published was evaluated using the methodology developed in the scope of EuroFIR. This includes the evaluation of the measurement and the sampling methods [16]. Briefly, this method evaluates seven categories: food description, component identification, sampling plan, number of analytical samples, sample handling, sample analysis and analytical quality control. Quality was scored in each one by answering a total of 28 predefined questions (criteria). For each category several criteria were defined and for each one the evaluator should answer "Yes", "No" or "Not Applicable" (when the criterion is not relevant for the nutrient in appreciation). These answers were translated quantitatively, accordingly the following answers points scheme: "Yes", 5 points; "No" and "Not Applicable", 0 points. The total points in each category were divided by the total number of "Yes" and "No"; by definition when one category gets only "No" or "Not Applicable" answers, the score should be 1. Through this evaluation, each category received a score between 1 (low quality) and 5 (high quality). At the end, the scores of each category were added and the overall quality index ranged between 7 (low quality) and 35 (high quality). The evaluation was done for all papers collected and, for each category and overall quality index, means were calculated.

\section{Results and Discussion}

\subsection{Data Collection}

The search tools of b-on was not selective enough and a general review of the abstracts resulting from the search, which returned initially $>1000$ results, was necessary. After this review, 373 references were collected and from these 25 were rejected, the main cause being the determination of carotenoids by spectrophotometric method instead of HPLC/UHPLC. The time frame was from 1990 to 2018, with emphasis on the most recent years. The year with the most papers was 2016. The references were from Archives of Biochemistry and Biophysics, Crop Science, European Food Research and Technology, Food and Nutrition Research, Food Chemistry, Food Research International, Food Science and Technology International, International Journal of Food Science and Technology, International Journal of Food Sciences and Nutrition, Journal of Agricultural and Food Chemistry, Journal of Chromatography A, Journal of Food Composition and Analysis, Journal of Food Science, Journal of Food, Agriculture and Environment, Journal of Separation Science, Journal of the Science of Food and Agriculture, LWT-Food Science and Technology, Nutrición Hospitalaria, Plant Foods for Human Nutrition, Planta, Postharvest Biology and Technology, Archivos Latinoamericanos de Nutrición, Food and Nutrition Bulletin, Revista do Instituto Adolfo Lutz and Scientia Horticulturae. Although b-on has a high journal coverage, digital object identifier (DOI) was not available in some of the oldest references, forcing a new internal referencing of these papers in order to create a unique identification.

To facilitate comparisons, all carotenoid content units were converted to $\mu \mathrm{g} / 100 \mathrm{~g}$, preferably in fresh weights, unless water content was not given, and in this case, the dry 
basis was flagged. The vast majority of papers did not report water content despite this parameter is key in order to be able to relate compositions in food composition databases.

The information about the use or not of saponification during the analytical process was collected as this reaction can lead to important losses of carotenoids or even the formation of artifacts, decreasing the accuracy of the analysis. To monitor this process, an internal standard is often added by some researchers, for example $\beta$-apo- $8^{\prime}$-carotenal or echinenone. Despite being a lengthy step, saponification is often essential to hydrolyze the carotenoid esters, to eliminate lipids and eliminate chlorophylls [1,2]. However, only $10 \%$ of the papers refer the inclusion/not inclusion of this step.

In general, the part of the food analyzed was mentioned in the papers. The descriptor "edible part" was used very often. However, in foods that may generate ambiguities, a more detailed description will be an asset. This is the case, for example, of apple, pear, tomato and apricot, in which the peel may or may not be considered an edible part, influencing the carotenoid content.

All food items were codified by FoodEx2, using the exposure hierarchy, including facets for processed food. This classification system, initially developed for exposure evaluation to contaminants, is currently increasingly used in the area of food composition and mandatory in projects supported by EFSA. It is less complex in relation to other systems (e.g., LanguaL) and it is used by EFSA to facilitate the compatibility/comparability among different domains of food databases and from different countries at the EU level.

Supplementary Tables S1-S10 [19-180], corresponding to 10 level 1 FoodEX2 groups, Coffee, cocoa, tea and infusions; Seasoning, sauces and condiments; Composite dishes; Fruit and vegetable juices and nectars; Animal and vegetable fats and oils and primary derivatives thereof; Fruit and fruit products; Legumes, nuts, oilseeds and spices; Starchy roots or tubers and products thereof, sugar plants; Vegetables and vegetable products; Grains and grain-based products present the carotenoid content of food items. Sub tables by FoodEX2 subgroups (levels 2-4) and the respective codes, including facets (represented by \#) were also used to obtain more discrimination and facilitate consultation.

The lack of quantitative data for a carotenoid in the tables meant in many cases that the carotenoid was not reported in the paper and not that the food did not contain that carotenoid. This has been common for the colorless carotenoids phytoene and phytofluene, which have been very often ignored [2].

Supplementary Tables S1-S10 contain 3507 values of carotenoid content, with $29.4 \%$ referring to $\beta$-carotene, $18.8 \%$ to lutein, $10.3 \%$ to $\beta$-cryptoxanthin, $8.8 \%$ to zeaxanthin, $7.0 \%$ to $\alpha$-carotene and $3.9 \%$ to lycopene.

Excluding foods analyzed in their dry form, and according to this collection, the major sources of the carotenoids above were, in $\mu \mathrm{g} / 100 \mathrm{~g}$ fresh weight, in descending order (extracts of Tables S1-S10 for some of these foods area presented on Appendix A):

- Carrot, spinach, goosefoot, peppers (red) and sheep sorrel for $\beta$-carotene.

- Spinach, goosefoot, sheep sorrel, Indian spinach and amaranth for lutein.

- Peppers (red), apricot, sarsaparilla, tamarillo and mandarin for $\beta$-cryptoxanthin.

- Peppers (red), goosefoot, duckweed, goji berries and maize for zeaxanthin.

- Carrot, pumpkin, carrot greens, cowpea and Ceylon spinach for $\alpha$-carotene.

- Tomato, rosehip, ketchup, watermelon and tomato sauce for lycopene.

\subsection{Data Quality Index}

Sample analysis and the component identification obtained immediately the maximum score, which was 5. Firstly, since HPLC (or more recently UHPLC) is the method generally accepted as suitable for the analysis of individual carotenoids, only data obtained using it were considered for data collection. Additionally, only clear unequivocal identified and quantified (including units) carotenoids were included in the database. The score for the number of analytical samples was 1 due to the specification of this gathering per analytical sample. Indeed, this category was not evaluated. The results of the global evaluation of all papers are presented in Figure 1, excluding categories evaluated a priori based on 
the assumptions of this collection. Considering the set of papers reviewed, the average scores obtained were 4 for the Food description, 5 for the Component identification, 2 for the Sampling plan, 1 for the Number of analytical samples, 4 for the Sample handling, 5 for the Sample analysis and 3 for the Analytical quality control. Considering that seven categories were under evaluation and that each one can get a maximum score of 5, overall, a mean rating of 24 out of a possible maximum of 35 was obtained by applying strictly the method. Considering the peculiarity of this collection it could be considered that a score of 23 out of 30 was obtained. Taking into account the EuroFIR criteria for quality of food composition databases, the results reveal that the data on carotenoids, available in the scientific literature present a greater weakness in terms of the sampling plan and then in terms of analytical control. This can be attributed to the difficulty in defining representative food sampling plans, the intention of the study (for instance the representativeness of the food in the country is not usually an important aspect) or the scarcity of certified reference materials/interlaboratory tests in this area. Another important aspect is that researchers from other areas may not be aware for the importance of these quality parameters and may not describe them in their publications.

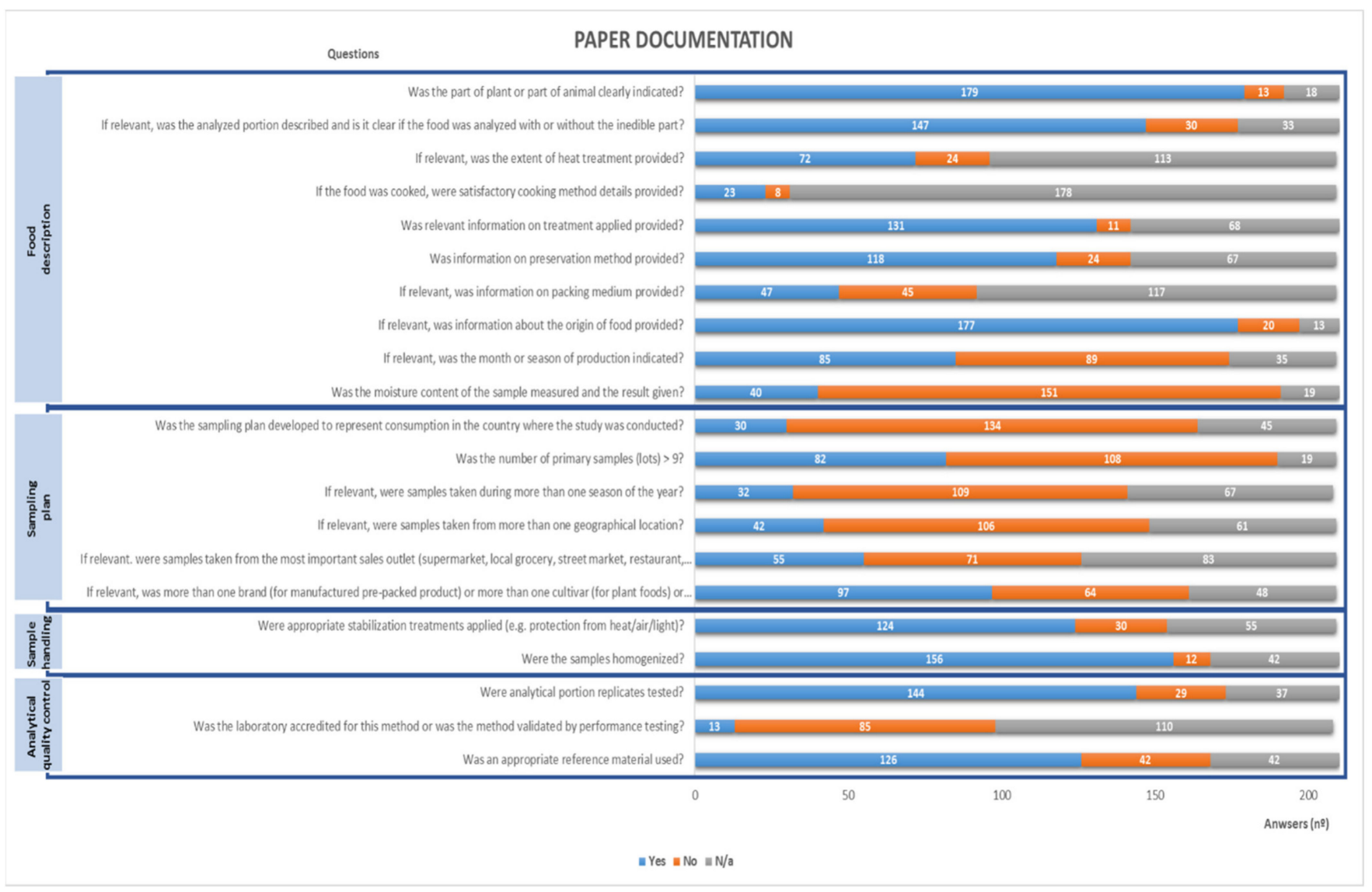

Figure 1. Paper documentation evaluation, for food composition databases, by the EuroFIR system.

\subsubsection{Factors Affecting the Level of Carotenoids}

The data collected show great variations in the levels of carotenoids within and across plant foods (Tables S1-S10). All plant biosynthesize carotenoids in their photosynthetic tissues following a quite constant pattern in most cases, whereas many of them also biosynthesize a wider variety of them in structures such as fruits, several flower structures, tubers, seeds or roots $[181,182]$. Apart from the type of plant tissue there are manifold factors related to the accumulation of carotenoids in these foods, examples of some of which are outlined below. It is important to note that, because of the numerous factors 
governing the biosynthesis of carotenoids in plant foods, it is generally difficult to establish categorically the effect that a particular practice has on a given food. Thus, it is not uncommon to find in the bibliography that the effect of an agronomic practice is markedly different depending for instance on genetic factors or developmental stages.

\subsubsection{Factors Related to the Plant}

\section{Genetic Factors}

The carotenoid profile in qualitative terms is usually quite constant across many varieties, although there can also be spontaneous or targeted color mutations that result in varieties with a distinctive carotenoid pattern. Thus, most sweet oranges (Citrus sinensis L. Osbeck) accumulate epoxycarotenoids (typically certain isomers of violaxanthin and antheraxanthin) as major carotenoids [55], whereas a few cultivars such as Cara Cara, Shara or Hong Anliu have a reddish flesh due to the accumulation of large amounts of lycopene (absent in most orange varieties) and also of the colorless carotenoids phytoene and phytofluene $[52,183]$. On the other hand, the variety Pinalate has a yellowish pulp resulting from the very high accumulation of $\zeta$-carotene, phytoene and phytofluene, which are the main carotenoids in this variety [184]. There are also tomato color mutants, for instance the R tomato, which has yellowish flesh and does not accumulate carotenoids [185] or the Delta tomato, with increased $\delta$-carotene levels (a carotenoid not usually detected in most tomato varieties) and reduced lycopene contents [186].

In some cases, structures that do not accumulate carotenoids or that accumulate very low amounts can become good sources of these compounds as a result of spontaneous mutations. One example would be the cauliflower, where a gene mutation results in the accumulation of high levels of $\beta$-carotene in the inflorescence and other structures [187]. The accumulation of carotenoids in previously non-carotenogenic structures can also be achieved by means of genetic engineering. The biosynthesis of $\beta$-carotene in the endosperm of golden rice being an excellent example [188].

On the other hand, there can be important differences in the carotenoid levels even within the same variety under the same cultivation conditions. Thus, for instance, in a study where the accumulation of carotenoids, tocopherols and phenolic compounds in diverse tomato and wild relatives was studied it was concluded that, when ripe, the highest levels of lycopene, phytoene and phytofluene were found in two accessions of the same tomato variety (var. cerasiforme). The differences ranged between ca. 2-fold (lycopene) and ca. 6-fold (phytoene), which highlights the impact that the genotype has in the accumulation of secondary metabolites [189].

\section{Ripening}

In carotenogenic fruits, ripening is normally accompanied by the degradation of chlorophylls and the increase in the biosynthesis of carotenoids although there are some exceptions. Thus, in fruits that remain green when ripe (kiwi) or those that owe their final color to anthocyanins (strawberries and other berries and olives) the carotenoid content can decrease over ripening [182].

\section{Part of the Tissue}

The carotenoid content is not normally evenly distributed in the plant structures. Indeed, it can vary considerably both longitudinally and transversally as it can be observed with the naked eye in foods like tomato fruits or carrots. Considering this is essential when generating compositional data on carotenoids [86]. A correct sampling procedure would involve, among many other steps, to quarter longitudinally the sample and then take and combine opposite sections [190].

Location of the Fruit in the Plant

The position of a carotenogenic fruit in the plant can have an important effect in their carotenoid levels. As an example, statistically significant differences in carotenoid contents 
have been reported in diverse tomato genotypes as a function of the location of the tomato clusters, although a consistent pattern of changes valid for all carotenoids and varieties was not observed. The authors argued that differences in the carotenoid content depending on the location could be due to differences in exposure to radiation [141], which is a factor known to affect carotenoid biosynthesis, as discussed below.

\subsubsection{Ambient Factors}

Light Quality

It is well known that the spectral quality of the light that reaches the plant can have an impact in the biosynthesis of secondary metabolites. Thus, the use of shade nettings that allow for the selection of the desired spectral light is becoming an important technological concept in agronomy [191]. As an example, it has been reported that blue light can have a positive impact on the accumulation of lycopene and $\beta$-carotene in tomatoes [133]. On the other hand, short-term ultraviolet B (UV-B) irradiation on sweet basil did not lead to marked increases in the carotenoid levels of young plants and decreased them in flowering plants [192].

\section{Light Quantity}

The effect of high light exposure or intensity on the levels of not only carotenoids but also other secondary metabolites is thought to be positive in general [193]. For example, high light exposure can lead to increases in total carotenoids in the peel of apples [194] or in tomatoes [132].

Interestingly, the fine tuning dosage of blue light could be a good strategy to increase the chlorophyll and carotenoid levels of microgreens like parsley, mustard or beet, where increases in these compounds ranging from 1.2-fold to 4.3-fold have been observed [110].

Climate, Season and Geographic Site of Production

Climate is a complex phenomenon that is interrelated with factors including season or geographical location, among others.

Some studies carried out in Brazil with papayas [195], West Indian cherry [182] or mangoes [196] indicate that, in some cases, climatic factors can have a greater impact on the biosynthesis of carotenoids than cultivar differences and that greater exposure to sunlight and higher temperatures can elevate the carotenoid levels in some fruits. In some cases, 5-6-fold differences in the levels of carotenoids between different geographical regions were observed [182]. A similar conclusion was drawn from a study in which the carotenoid levels in diverse tomatoes grown in Ireland and Spain were compared [131].

Concerning seasonal effects, significant differences in the levels of both total and some individual carotenoids of kale have been reported, the total carotenoid content being higher in winter than in summer, 1.25-fold for cultivar cv. Manteiga [197] and 2-fold for galega v. acephala [32]. In a study in which the effect of regulated deficit irrigation, cluster, developmental stages and two seasons (autumn and spring) on the carotenoid levels of "Lazarino" and "Summerbrix" tomatoes was evaluated, it was concluded that, overall, lower levels of individual and total carotenoids were observed in autumn [198].

Features of climate changes, for instance the increase in temperature, the elevated atmospheric $\mathrm{CO}_{2}$ and the arrival of more UVB rays on Earth due to the decrease in the ozone layer seems to influence the content of carotenoids in food. In an experimental study the influence of temperature on total carotenoid content was evaluated and it was found that the total carotenoid content of five tomato varieties was lower at $35.4{ }^{\circ} \mathrm{C}$ than at $33.4^{\circ} \mathrm{C}$ [199]. A meta-analysis conducted showed that in general an exposure of plants to high levels of $\mathrm{CO}_{2}$ decreased the content of carotenoids by $15 \%$, with some exceptions, mainly when the plants were abiotically stressed, in which the concentration of carotenoids increased [200]. Plantains grown in the south hemisphere contained the more carotenoids provitamin A, $\alpha$-carotene and $\beta$-carotene the greater the incidence of UVB rays [201]. 


\subsubsection{Agronomic Practices}

Salinity Stress

Diverse treatments leading to salinity stress have been shown to increase lycopene and other carotenoid levels (in some cases up to 3-fold) in different tomato genotypes [127,134]. Salinity stress has also been shown to lead to elevated carotenoid contents in red pepper [202] and, more markedly, in romaine lettuce [103].

\section{Water Deficit}

The availability of water is an important problem in many parts of the world, so the importance of implementing practices leading to efficient water usage in agriculture continues growing. The effect of water stress or deficit irrigation on the commercial quality or other parameters, like the levels of secondary metabolites, is therefore a timely research topic. As an example, it has been observed that a regulated deficit irrigation with a reduction of $40-50 \%$ in the leaf water potential in some tomato varieties can lead to increases in the levels of not only carotenoids but also phenolic compounds without affecting significantly their commercial quality. More specifically, ca. 1.5-fold increases in lycopene and total carotenoid levels were observed in some cases [141]. Deficit irrigation has also been reported to reduce yield, but not lycopene and fruit quality in certain watermelon varieties [203]. Interestingly, grafting of mini-watermelon under irrigation deficit led to increases of lycopene levels ca. $40 \%$ compared to the ungrafted counterparts [204]. Grafting under water stress could also lead to increases in lycopene levels in cherry tomatoes [205]. Contrastingly, regulated deficit irrigation has also been shown to reduce carotenoid levels in peaches [206]. On the other hand, water stress has been reported to significantly reduce the levels of capsanthin in red peppers, the degree of reduction being related to the intensity of the stress [207].

Use of Agrochemicals

As part of an interesting study, the carotenoid levels of kales cv. "Manteiga" grown in a farm not using agrochemicals were compared with those grown in a neighboring farm that used glyphosate (herbicide), ethyl parathion (insecticide) and a leaf fertilizer containing nitrogen, phosphorus and potassium. The results indicated that the total carotenoid contents were significantly higher (1.2-fold) in the farm not using agrochemicals [182,198]. Significantly higher lycopene contents (ranging from 1.6-fold to 2-fold) were found in Rio Red grapefruits grown conventionally (using diverse fertilizers and products for pest and weed control) relative to organically-grown counterparts in a study in which the fruits were harvest at the early, mid and late season for three consecutive years [54]. There is also evidence that fertilization with nitrogen can affect positively the accumulation of carotenoids in red pepper [208] and carrot [209] and negatively in tomatoes [210], whereas phosphorous or potassium can have a positive effect in this crop [210].

\subsection{Post-Harvest Treatments, Industrial Processing, Cooking and Storage Conditions}

These topics are dealt with in detail elsewhere. In general, the losses of carotenoids increase with the intensity and the time of the treatments, with important differences among matrices and carotenoid species [118,211].

It is well-known that the synthesis of carotenoids can continue after harvest if the carotenogenic material remains intact, hence the carotenogenesis can be controlled to some extent by modulating parameters such as temperature, atmosphere or light, among others. Again, different behavior due factors including matrices, carotenoid species or conditions of the treatment have been reported. For instance, freezing storage for 6 months had no significant effect on $\beta$-carotene content of peas and carrots, although frozen storage for one year led to a decrease in $\alpha$ - and $\beta$-carotene in processed carrots [211].

It is very important to note that very frequently; published papers report that industrial processing or cooking lead to increases of the levels of carotenoids, these results being in most cases erroneous. Thus, in most cases the treatments inactivate proteins (including 
of course carotenogenic enzymes) and leads to carotenoid degradation. Claims about enhanced levels of carotenoids as a result of such industrial or culinary treatments should be accompanied by supporting evidence, for instance upregulation of carotenogenic genes or downregulation of genes encoding carotenoid oxygenases, which cleave carotenoids into retinoids, apocarotenoids or other products [13].

Another reason is that, very frequently, those treatments enhance the extractability of carotenoids from treated compared to raw matrices due to the changes such as the softening of membranes or walls [182,212]. In relation to this, it is important to note that, depending on the conditions; some treatments can decrease the content of carotenoids in the food but enhance their release from it during digestion, having therefore a potential positive impact on their bioavailability. Examples of this have been reported in carrot [166], tomato [138] and orange products [37], among others. On the other hand, sometimes, an important source of error is that the changes in the weight of the processed or cooked food are not taken into account; hence, the reported retentions of carotenoids are not realistic. Several formulae for their calculation are recommended in a reference text by Rodriguez-Amaya [182]:

\footnotetext{
$\%$ retention $=($ carotenoid content per $\mathrm{g}$ of cooked food $\times \mathrm{g}$ of food after cooking $/$ carotenoid content per $\mathrm{g}$ of raw food $\times \mathrm{g}$ of food before cooking $) \times 100$

$\%$ retention $=$ carotenoid content per $\mathrm{g}$ of cooked food (dry basis) $/$ carotenoid content per $\mathrm{g}$ of raw food (dry basis) $\times 100$

$\%$ retention $=$ carotenoid content $($ after cooking) per $\mathrm{g}$ of original raw food/carotenoid content per $\mathrm{g}$ of raw food $\times 100$
}

Apart from losses of carotenoids during processing, cooking and/or storage other phenomena including geometrical isomerization [213,214] or 5,6-epoxide to 5,8-furanoid rearrangements can take place $[31,197]$. Given that both kind of isomerizations are accompanied by changes in the light absorption spectra [186], noticeable food color changes as a result of them could be expected in some cases.

Taken together, it can be readily inferred that the levels of carotenoids do vary considerably in any food even in set of samples from the same geographical area. As some examples of this fact in samples analyzed in the same laboratory, 18-20-fold differences have been reported in marketed orange juices and tomato fruits $[31,140,215]$ and 60 -fold differences in olive oils [216].

\section{Conclusions and Research Needs}

The carotenoid analytical data collected for this work, showed a good average quality index, 24/35, according to the EuroFIR classification. It has been concluded that there is the need to improve the description and/or allocation of more resources to the definition of sampling plans and to the external control of the laboratory analytical methods to increase the number of traceable and comparable results. Only a complete analytical method validation, including accuracy evaluation, enables the estimation of the uncertainty of the measurement results (topic mentioned in only two of the publications analyzed) in order to assess its impact on studies based on dietary carotenoid content and in the assessment of actual differences in carotenoid levels. The uncertainty evaluation will also enable the definition of the number of significant figures of the results, avoiding the false impression of high accuracy of the results published with too many significant figures without support.

The analytical methods used to obtain the collected data generally included several mass transfer steps and in some cases a saponification reaction, which do lead to carotenoid losses, Hence it is important to mention clearly when the saponification step is included and measures taken to correct for losses (e.g., internal standards choice). On the other hand, the complete separation of the carotenoids in the chromatographic columns is in some cases difficult and requires specialized technicians.

The investment in faster analytical methods, less prone to error and using more environmentally friendly reagents and in less quantity will be an asset for the determination of carotenoids in foods. The analytical distinction between the $E$ and $Z$ isomers 
of the different carotenoids may be important to gain further insight into differences in bioaccessibility/bioavailability, vitamin A activity and other bioactivities.

Foods contain different carotenoids in different levels, so it is advisable to consume a diversified diet to obtain appropriate levels of the major health-promoting dietary carotenoids. This approach is also advised in the case of contaminants to minimize exposure to each contaminant.

Although food carotenoid databases are very useful tools to establish recommended intakes, bioaccessibility/bioavailability studies and more integrated studies considering all $\mathrm{diet} /$ components/individuals interactions are also needed as the carotenoid status depend on factors depending on the matrix, other dietary components and the individual. Although there is ample evidence that a diet rich in fruits and vegetables (e.g., Mediterranean Diet) has positive effects on human health and, establishing recommendations for dietary carotenoids intakes would contribute to reinforcing the education/informed choices by the population. In addition, it could contribute to decrease the consumption of heavily processed foods, which are often rich in saturated fat, sugar and salt. Provitamin A carotenoids are particularly very important for populations with limited availability of animal foods or for those that do not eat them by choice. In line with this fact, it is important to improve their conversion into vitamin A activity, overcoming limitations of RA and RAE formulas, and to appropriately consider them in the nutritional labeling of foods.

The wide variations in the carotenoid contents in different varieties/cultivars/landraces/ accessions of a certain species illustrate the importance and the need for their documentation in food composition databases. This collection includes little consumed foods with very high levels of carotenoids (for instance rosehip or sarsaparrilla). This can contribute to take better advantage of biodiversity to enhance the carotenoid intake in particular. This database can be useful to include the carotenoid content/nutritional value criterion on the choice of varieties for agricultural cultivation, in addition to others such as high production or resistance to transport and pests. In environmental terms, studies on the carbon or water footprints of foods in general are also necessary as diet and environment are essential elements for human health.

Supplementary Materials: The following are available online at https://www.mdpi.com/article/10 .3390/foods10050912/s1, Table S1: Coffee, cocoa, tea and infusions (A03GG). Table S2: Seasoning, sauces and condiments (A042N). Table S3: Composite dishes (A03VA). Table S4: Fruit and vegetable juices and nectars (including concentrates) (A039K). Table S5: Animal and vegetable fats and oils and primary derivatives thereof (A036M). Table S6: Fruit and fruit products (A01BS). Table S7: Legumes, nuts, oilseeds and spices (A011X). Table S8: Starchy roots or tubers and products thereof, sugar plants (A00ZR). Table S9 Vegetables and vegetable products (A00FJ). Table S10: Grains and grain-based products (A000J).

Author Contributions: Conceptualization, M.G.D. and A.J.M.-M.; Data curation, M.G.D., G.I.A.B., K.K., A.I.M., P.M.-B., B.O.-A., A.M.P., F.R., V.T.Š., J.S., L.V.-M., J.J.V. and A.J.M.-M.; Funding acquisition, A.J.M.-M.; Methodology, M.G.D.; Writing—original draft, M.G.D., G.I.A.B., K.K., A.I.M., P.M.-B., B.O.-A., A.M.P., F.R., V.T.Š., J.S., L.V.-M., J.J.V. and A.J.M.-M.; Writing-review and editing, M.G.D., G.I.A.B., K.K., A.I.M., P.M.-B., B.O.-A., A.M.P., F.R., V.T.Š., J.S., L.V.-M., J.J.V. and A.J.M.-M. All authors have read and agreed to the published version of the manuscript.

Funding: This research article is based upon work from COST Action EUROCAROTEN (European network to advance carotenoid research and applications in agro-food and health, CA15136, www. eurocaroten.eu; accessed on 1 February 2021), supported by COST (European Cooperation in Science and Technology, http:/ / www.cost.eu/; accessed on 1 February 2021).

Institutional Review Board Statement: Not applicable.

Informed Consent Statement: Not applicable.

Acknowledgments: Quality technical assistance from Ana Benítez (UE) and of Milana Rosul (IFTNS) is acknowledged.

Conflicts of Interest: The authors declare no conflict of interest. 


\section{Appendix A}

Table A1. Root and tuber vegetables (excluding starchy- and sugar-) (A00QF) ( $\mu \mathrm{g} / 100 \mathrm{~g})$.

\begin{tabular}{|c|c|c|c|c|c|c|c|c|c|c|}
\hline Food Name & Scientific Name & $\begin{array}{l}\text { Origin } \\
\text { (Country) }\end{array}$ & $\begin{array}{l}\text { Purchase } \\
\text { (Country) }\end{array}$ & Water $(\%)$ & $\begin{array}{c}\text { Part } \\
\text { Analysed }\end{array}$ & Colour & $\alpha$-Carotene & $\beta$-Carotene & $\beta$-Cryptoxanthin & Ref. \\
\hline Carrot & Daucus carota L. & $\begin{array}{l}\text { United } \\
\text { Kingdom }\end{array}$ & $\begin{array}{l}\text { United } \\
\text { Kingdom }\end{array}$ & & peeled & & $4450 \pm 940$ & $32,000 \pm 2880$ & & [95] \\
\hline Carrot & Daucus carota L. & Italy & Italy & & & & $2840-4960$ & $4350-8840$ & & [25] \\
\hline Carrot & Daucus carota L. & Germany & Germany & 91.3 & edible part & & 4890 & 9020 & & [53] \\
\hline Carrot & Daucus carota $\mathrm{L}$. & Germany & Germany & 84.3 & edible part & & 3060 & 6500 & 12 & [53] \\
\hline Carrot & Daucus carota L. & Germany & Germany & & edible part & & 4120 & 4650 & 28 & [53] \\
\hline Carrot & Daucus carota $\mathrm{L}$. & Spain & Spain & & edible part & orange & 2895 & 6628 & & [24] \\
\hline Carrot & Daucus carota $\mathrm{L}$. & Spain & Spain & & edible part & orange & 3700 & 9800 & & [24] \\
\hline Carrot & Daucus carota $\mathrm{L}$. & Turkey & Turkey & & root & orange & $1344-3011$ & $4160-7162$ & & [156] \\
\hline Carrot & Daucus carota L. & Spain & Spain & & edible part & & 3245 & 8162 & & [24] \\
\hline Carrot & Daucus carota $\mathrm{L}$. & Spain & Spain & & edible part & & 2895 & 6628 & & [24] \\
\hline Carrot & Daucus carota $\mathrm{L}$. & Italy & Italy & & all sample & $\mathrm{L}^{*} 52.2 \pm 0.7 \mathrm{a}^{*} 24.1 \pm 1.5 \mathrm{~b}^{*} 36.1 \pm 1$ & $82,100 \pm 1100$ & $128,400 \pm 800$ & & [111] \\
\hline Carrot & Daucus carota $\mathrm{L}$. & Italy & Italy & & all sample & $L * 52.1 \pm 0.8 a^{*} 22.6 \pm 1.1 b * 35.7 \pm 1.9$ & $85,600 \pm 2400$ & $101,600 \pm 700$ & & [111] \\
\hline Carrot & Daucus carota $\mathrm{L}$. & Poland & Poland & & roots & & & $4820-9520$ & & [157] \\
\hline Carrot & $\begin{array}{c}\text { Daucus carota L. } \\
\text { cv Nerac }\end{array}$ & Ireland & Ireland & & roots & & & $188,000 \pm 5000$ & & [158] \\
\hline Carrot & $\begin{array}{l}\text { Daucus carota } \mathrm{L} \text {. } \\
\text { cv. Nantes }\end{array}$ & Brazil & & & tuber & orange & 3500 & 6150 & nd & [109] \\
\hline Carrot & $\begin{array}{c}\text { Daucus carota } \mathrm{L} . \\
\text { HCM }\end{array}$ & France & France & & root & dark-orange & $7583 \pm 619$ & $17,206 \pm 643$ & & [159] \\
\hline Carrot & $\begin{array}{l}\text { Daucus carota } \mathrm{L} \text {. } \\
\text { subsp. sativus }\end{array}$ & Finland & Finland & & & & $2200-4900$ & $4600-10,300$ & & [86] \\
\hline Carrot & $\begin{array}{l}\text { Daucus carota } \mathrm{L} \text {. } \\
\text { subsp. sativus }\end{array}$ & Spain & Spain & & & & $2900 \pm 300$ & $6600 \pm 0$ & & [86] \\
\hline Carrot & $\begin{array}{l}\text { Daucus carota } \mathrm{L} \text {. } \\
\text { subsp. sativus }\end{array}$ & $\begin{array}{l}\text { United } \\
\text { Kingdom }\end{array}$ & $\begin{array}{l}\text { United } \\
\text { Kingdom }\end{array}$ & & & & $2700-3600$ & $8500-10,800$ & & [86] \\
\hline
\end{tabular}


Table A1. Cont.

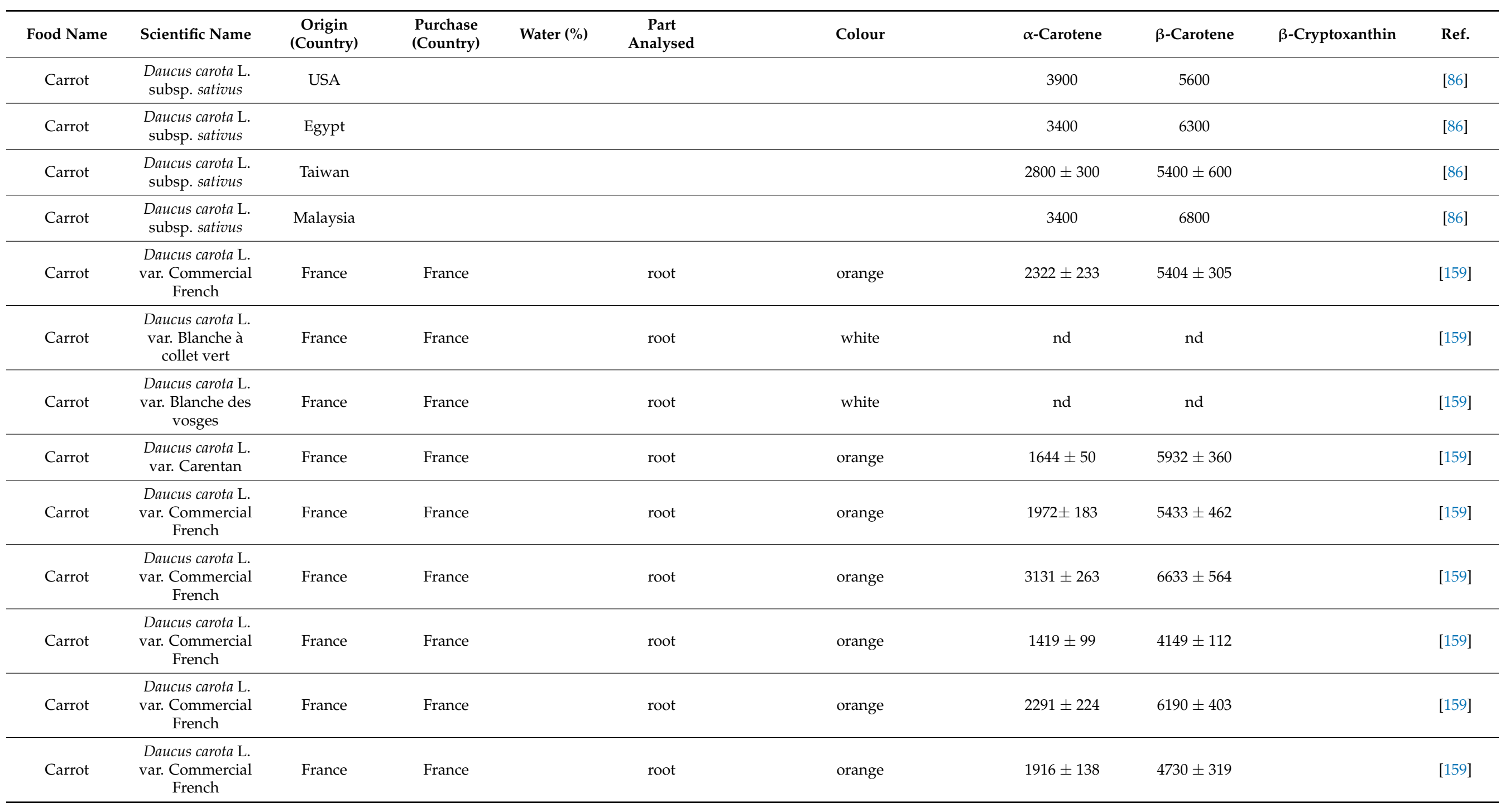


Table A1. Cont.

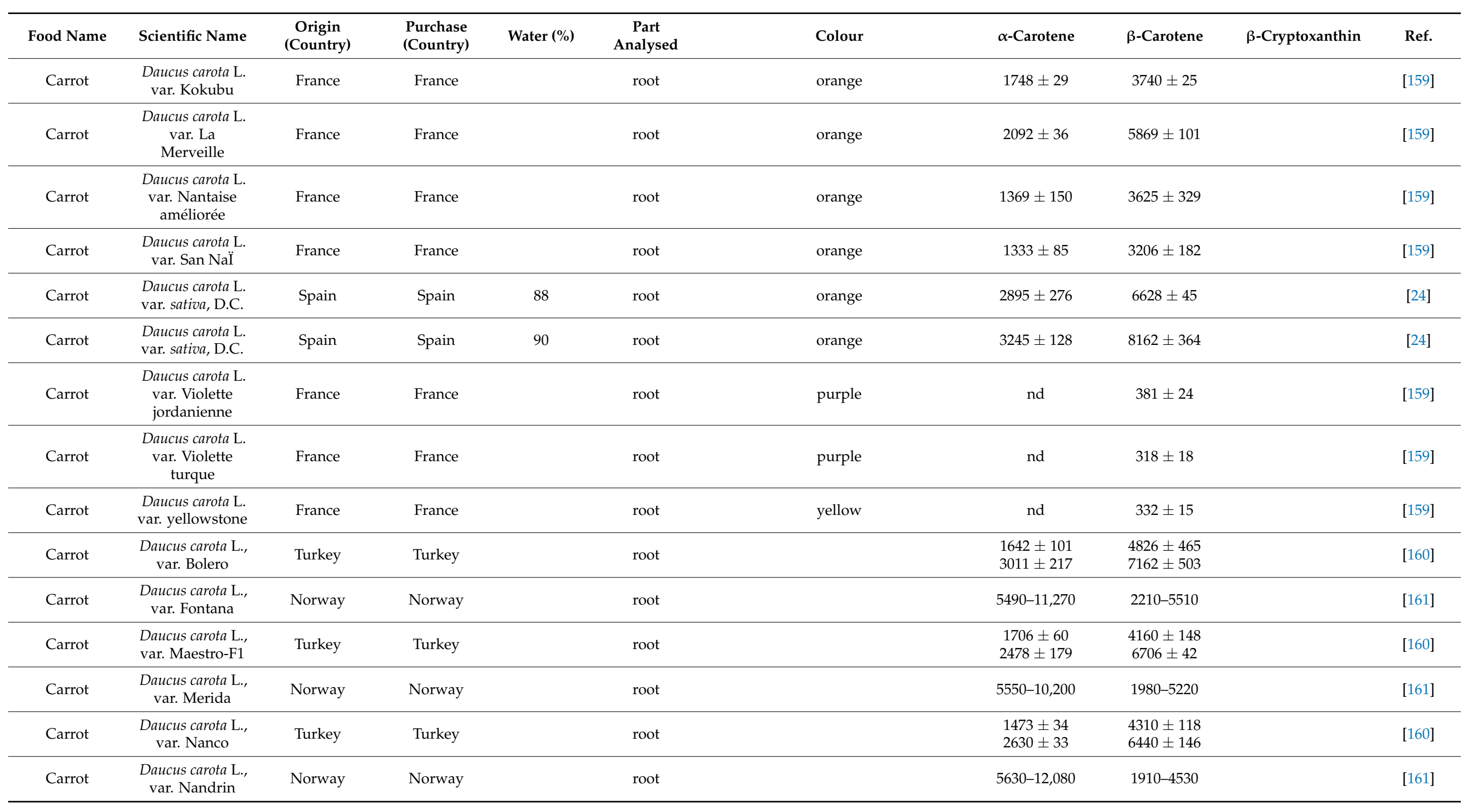


Table A1. Cont.

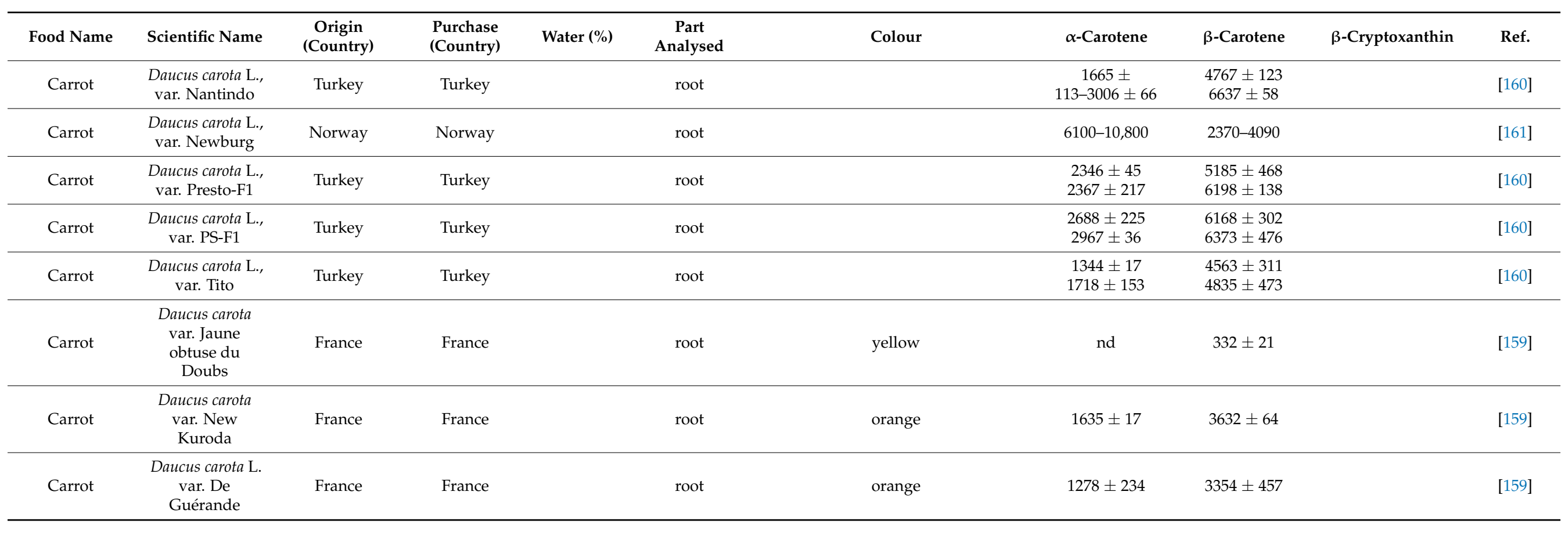


Table A2. Spinaches and similar (A00MH) ( $\mu \mathrm{g} / 100 \mathrm{~g})$.

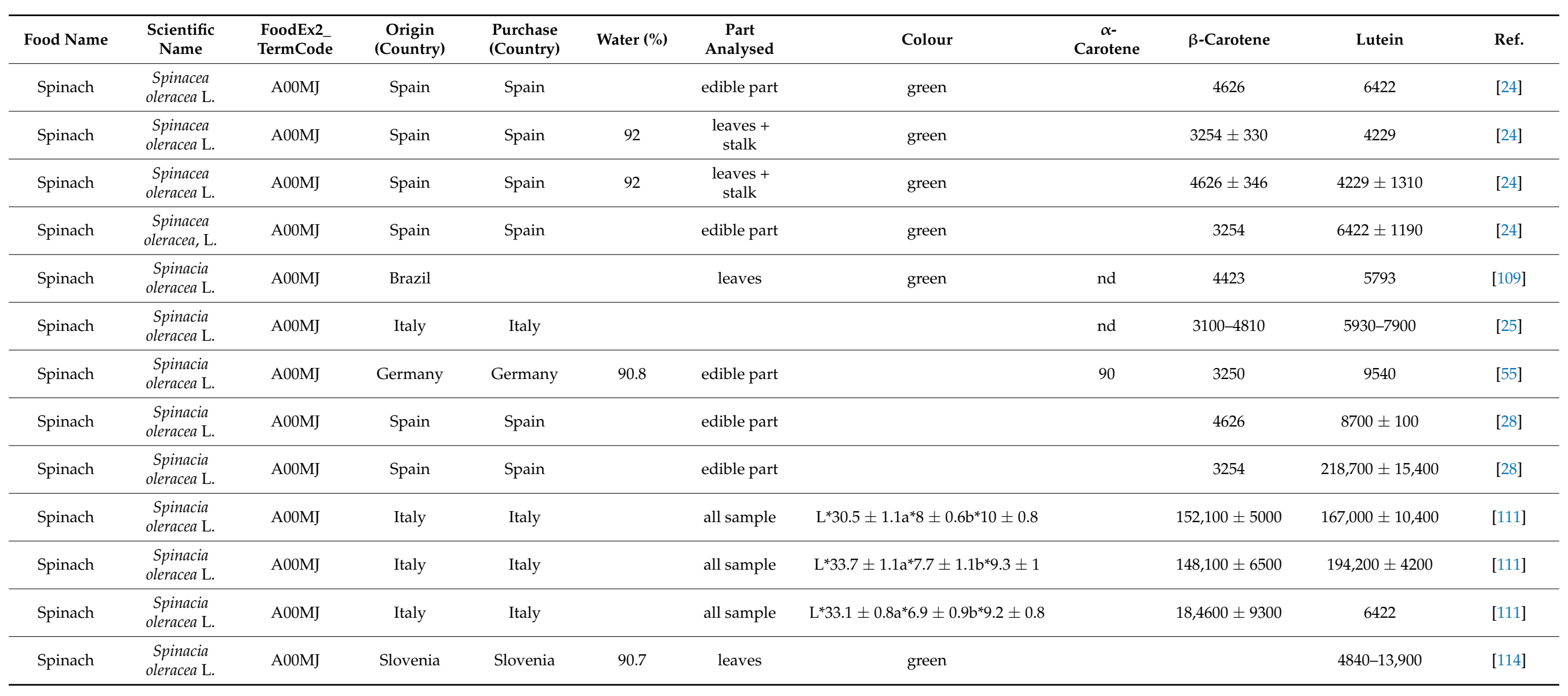


Table A3. Mandarins and similar (A01CB) ( $\mu \mathrm{g} / 100 \mathrm{~g})$.

\begin{tabular}{|c|c|c|c|c|c|c|c|c|c|c|c|c|c|c|c|c|}
\hline $\begin{array}{l}\text { Food } \\
\text { Name }\end{array}$ & $\begin{array}{l}\text { Scientific } \\
\text { Name }\end{array}$ & $\begin{array}{l}\text { FoodEx2 } \\
\text { TermCode }\end{array}$ & $\begin{array}{c}\text { Origin } \\
\text { (Country) }\end{array}$ & $\begin{array}{l}\text { Purchase } \\
\text { (Country) }\end{array}$ & $\begin{array}{c}\text { Water } \\
(\%)\end{array}$ & $\begin{array}{c}\text { Part } \\
\text { Analysed }\end{array}$ & Colour & $\begin{array}{l}\text { E(v. Trans)- } \alpha- \\
\text { Carotene }\end{array}$ & $\begin{array}{l}\text { E(v. Trans)- } \beta- \\
\text { Carotene }\end{array}$ & $\begin{array}{c}\beta- \\
\text { Cryptoxanthin }\end{array}$ & Lutein & Phytoene & Phytofluene & Violaxanthin & Zeaxanthin & Ref. \\
\hline Mandarin & $\begin{array}{c}\text { Citrus } \mathrm{cv} \\
\text { Mediterranean }\end{array}$ & $\mathrm{A} 01 \mathrm{CD}$ & Italy & Italy & & $\begin{array}{l}\text { essential oil of } \\
\text { peel fruit } \\
\text { (free) }\end{array}$ & & & & $610 \pm 62$ & & & & & & [58] \\
\hline Mandarin & $\begin{array}{c}\text { Citrus } \mathrm{cv} \\
\text { Mediterranean }\end{array}$ & $\mathrm{A} 01 \mathrm{CD}$ & Italy & Italy & & $\begin{array}{l}\text { essential oil of } \\
\text { peel fruit } \\
\text { (laurate) }\end{array}$ & & & & $1411 \pm 140$ & & & & & & [58] \\
\hline Mandarin & $\begin{array}{c}\text { Citrus } \mathrm{cv} \\
\text { Mediterranean }\end{array}$ & $\mathrm{A} 01 \mathrm{CD}$ & Italy & Italy & & $\begin{array}{c}\text { essential oil of } \\
\text { peel fruit } \\
\text { (myristate) }\end{array}$ & & & & $1504 \pm 132$ & & & & & & [58] \\
\hline Mandarin & $\begin{array}{c}\text { Citrus cv } \\
\text { Mediterranean }\end{array}$ & $\mathrm{A} 01 \mathrm{CD}$ & Italy & Italy & & $\begin{array}{c}\text { essential oil of } \\
\text { peel fruit } \\
\text { (palmitate) }\end{array}$ & & & & $715 \pm 74$ & & & & & & [58] \\
\hline Mandarin & $\begin{array}{l}\text { Citrus deliciosa, } \\
\text { Ten. }\end{array}$ & $\mathrm{A} 01 \mathrm{CJ}$ & Spain & Spain & 86 & without skin & orange & & $213 \pm 102$ & $843 \pm 216$ & & & & & & [24] \\
\hline Mandarin & $\begin{array}{l}\text { Citrus deliciosa, } \\
\text { Ten. }\end{array}$ & $\mathrm{A} 01 \mathrm{CJ}$ & Spain & Spain & 85 & without skin & orange & & $130 \pm 10$ & $1106 \pm 63$ & & & & & & [24] \\
\hline Mandarin & Citrus reticulata & A01CD & Spain & Spain & & & orange & & 213 & 843 & & & & & & [24] \\
\hline Mandarin & $\begin{array}{l}\text { Citrus reticulata } \\
\text { Blanco cv. } \\
\text { Hansen }\end{array}$ & $\mathrm{A} 01 \mathrm{CE}$ & France & France & & juice fruit & & & 197 & 1500 & 163 & 446 & 500 & 467 (cis) & 128 & [43] \\
\hline Mandarin & $\begin{array}{l}\text { Citrus reticulata } \\
\text { Blanco cv. } \\
\text { Hansen }\end{array}$ & A01CE & $\begin{array}{c}\text { French } \\
\text { Polynesia }\end{array}$ & & & juice fruit & & & 76 & 916 & 210 & 24 & 92 & 560 (cis) & 131 & [43] \\
\hline Mandarin & $\begin{array}{l}\text { Citrus reticulate, } \\
\text { L. var. Tango }\end{array}$ & $\mathrm{A} 01 \mathrm{CD}$ & Spain & Spain & & fruit & orange & 12.4 & 547 & 1331.6 & & & & & & [56] \\
\hline
\end{tabular}


Table A4. Cereal grains (and cereal-like grains) (A000L) ( $\mu \mathrm{g} / 100 \mathrm{~g})$.

\begin{tabular}{|c|c|c|c|c|c|c|c|c|c|c|c|c|c|c|}
\hline $\begin{array}{l}\text { Food } \\
\text { Name }\end{array}$ & $\begin{array}{l}\text { Scientific } \\
\text { Name }\end{array}$ & $\begin{array}{l}\text { FoodEx2 } \\
\text { TermCode }\end{array}$ & $\begin{array}{c}\text { Origin } \\
\text { (Country) }\end{array}$ & $\begin{array}{l}\text { Purchase } \\
\text { (Country) }\end{array}$ & Saponification & $\begin{array}{c}\text { Part } \\
\text { Analysed }\end{array}$ & Colour & $\begin{array}{c}\alpha- \\
\text { Carotene }\end{array}$ & $\begin{array}{l}\text { (v. Trans)- } \alpha- \\
\text { Carotene }\end{array}$ & $\beta$-Carotene & $\begin{array}{l}\text { E(v. Trans)- } \\
\beta \text {-Carotene }\end{array}$ & $\begin{array}{c}\beta- \\
\text { Cryptoxanthin }\end{array}$ & $\begin{array}{l}\text { E(V. Trans)- } \\
\text { Lutein }\end{array}$ & Ref. \\
\hline Maize & Zea mays L. & A000T & Spain & Spain & & edible part & yellow & 33 & & 30 & & & & [24] \\
\hline Maize & Zea mays L. & A000T & Croatia & Croatia & & all sample & & & & $117.3 \pm 8.17$ & & $158.5 \pm 9.5$ & & [174] \\
\hline Maize & Zea mays L. & $\begin{array}{c}\text { A000T } \\
\text { \#F28.A07KQ } \\
\text { \$F28.A0BA1 }\end{array}$ & USA & & no & & & 15 & & & 14 & 0 & 202 & [28] \\
\hline Maize & Zea mays L. & A000T & Netherlands & Netherlands & & kernels & & & $20 \pm 7$ & & $424 \pm 6$ & & $157 \pm 3$ & [175] \\
\hline Maize & Zea mays L. & A000T & Netherlands & Netherlands & & kernels & & & $58 \pm 0$ & & $40 \pm 2$ & & $93 \pm 1$ & [175] \\
\hline Maize & Zea mays L. & $\mathrm{A} 000 \mathrm{~T}$ & Netherlands & Netherlands & & kernels & & & $3 \pm 1$ & & $246 \pm 8$ & & $453 \pm 8$ & [175] \\
\hline Maize & Zea mays L. & $\mathrm{A} 000 \mathrm{~T}$ & Netherlands & Netherlands & & kernels & & & $44 \pm 1$ & & $879 \pm 28$ & & $37 \pm 3$ & [175] \\
\hline Maize & Zea mays L. & A000T & Netherlands & Netherlands & & kernels & & & $41 \pm 7$ & & $448 \pm 15$ & & $260 \pm 10$ & [175] \\
\hline Maize & Zea mays L. & $\mathrm{A} 000 \mathrm{~T}$ & Netherlands & Netherlands & & kernels & & & $17 \pm 0$ & & $368 \pm 2$ & & $988 \pm 5$ & [175] \\
\hline Maize & Zea mays L. & $\mathrm{A} 000 \mathrm{~T}$ & Netherlands & Netherlands & & kernels & & & $23 \pm 2$ & & $56 \pm 2$ & & $37 \pm 2$ & [175] \\
\hline Maize & Zea mays L. & A000T & Netherlands & Netherlands & & kernels & & & $11 \pm 0$ & & $37 \pm 0$ & & $41 \pm 4$ & [175] \\
\hline Maize & Zea mays L. & A000T & Netherlands & Netherlands & & kernels & & & $16 \pm 3$ & & $303 \pm 16$ & & $251 \pm 8$ & [175] \\
\hline Maize & Zea mays L. & A000T & Netherlands & Netherlands & & kernels & & & $86 \pm 6$ & & $277 \pm 8$ & & $84 \pm 2$ & [175] \\
\hline Maize & Zea mays L. & $\mathrm{A} 000 \mathrm{~T}$ & Netherlands & Netherlands & & kernels & & & $23 \pm 1$ & & $305 \pm 20$ & & $371 \pm 15$ & [175] \\
\hline
\end{tabular}


Table A5. Cucurbits with inedible peel (A00KD) ( $\mu \mathrm{g} / 100 \mathrm{~g})$.

\begin{tabular}{|c|c|c|c|c|c|c|c|c|c|c|c|}
\hline Food Name & Scientific Name & $\begin{array}{l}\text { FoodEx2 } \\
\text { TermCode }\end{array}$ & $\begin{array}{l}\text { Origin } \\
\text { (Country) }\end{array}$ & $\begin{array}{l}\text { Purchase } \\
\text { (Country) }\end{array}$ & Water (\%) & Part Analysed & Colour & $\alpha$-Carotene & $\beta$-Carotene & $\beta$-Cryptoxanthin & Ref. \\
\hline Pumpkin & Cucurbita maxima & A00KH & Spain & Spain & & edible part & & & 490 & 60 & [24] \\
\hline Pumpkin & Cucurbita maxima & A00KH & Spain & Spain & & edible part & & 31 & 188 & & [24] \\
\hline Pumpkin & Cucurbita maxima & A00KH & Spain & Spain & & edible part & & 53 & 692 & & [24] \\
\hline Pumpkin & $\begin{array}{l}\text { Cucurbita maxima var. } \\
\text { Autumn Cup }\end{array}$ & A00KH & Austria & Austria & & flesh fruit & & 800 & 5200 & & [152] \\
\hline Pumpkin & $\begin{array}{l}\text { Cucurbita maxima var. } \\
\text { Buen Gusto }\end{array}$ & A00KH & Austria & Austria & & flesh fruit & & 1000 & 3300 & & [152] \\
\hline Pumpkin & $\begin{array}{l}\text { Cucurbita maxima var. Flat } \\
\text { white Boer }\end{array}$ & A00KH & Austria & Austria & & flesh fruit & & 7500 & 6200 & & [152] \\
\hline Pumpkin & $\begin{array}{l}\text { Cucurbita maxima var. } \\
\text { Gelber Zentner }\end{array}$ & A00KH & Austria & Austria & & flesh fruit & & 0 & 2200 & & [152] \\
\hline Pumpkin & $\begin{array}{c}\text { Cucurbita maxima var. } \\
\text { Hyvita }\end{array}$ & A00KH & Austria & Austria & & flesh fruit & & 990 & 2500 & & [152] \\
\hline Pumpkin & $\begin{array}{l}\text { Cucurbita maxima var. } \\
\text { Imperial Elite }\end{array}$ & А00KH & Austria & Austria & & flesh fruit & & 1100 & 7400 & & [152] \\
\hline Pumpkin & $\begin{array}{l}\text { Cucurbita maxima var. } \\
\text { Japan } 117\end{array}$ & A00KH & Austria & Austria & & flesh fruit & & 1000 & 7200 & & [152] \\
\hline Pumpkin & $\begin{array}{l}\text { Cucurbita maxima var. } \\
\text { Mini green Hubbard }\end{array}$ & $\mathrm{A} 00 \mathrm{KH}$ & Austria & Austria & & flesh fruit & & 420 & 1400 & & [152] \\
\hline Pumpkin & $\begin{array}{l}\text { Cucurbita maxima var. } \\
\text { Mishti kumra }\end{array}$ & $\mathrm{A} 00 \mathrm{KH}$ & Bangladesh & & & fruit & & & $362 \pm 89.3$ & & [157] \\
\hline Pumpkin & $\begin{array}{l}\text { Cucurbita maxima var. } \\
\text { Snow Delite }\end{array}$ & $\mathrm{A} 00 \mathrm{KH}$ & Austria & Austria & & flesh fruit & & 1500 & 6400 & & [152] \\
\hline Pumpkin & $\begin{array}{l}\text { Cucurbita maxima var. } \\
\text { Uchiki Kuri }\end{array}$ & $\mathrm{A} 00 \mathrm{KH}$ & Austria & Austria & & flesh fruit & & 1400 & 2500 & & [152] \\
\hline Pumpkin & $\begin{array}{l}\text { Cucurbita maxima var. } \\
\text { Umber Cup }\end{array}$ & $\mathrm{A} 00 \mathrm{KH}$ & Austria & Austria & & flesh fruit & & 790 & 3700 & & [152] \\
\hline Pumpkin & Cucurbita maxima & A00KH & Austria & Austria & & flesh fruit & & 900 & 4300 & & [152] \\
\hline Pumpkin & $\begin{array}{l}\text { Cucurbita maxima } \times \text { C. } \\
\text { moschata var. Tetsuka Buto }\end{array}$ & A00KH & Austria & Austria & & flesh fruit & & 2400 & 3500 & & [152] \\
\hline
\end{tabular}


Table A5. Cont.

\begin{tabular}{|c|c|c|c|c|c|c|c|c|c|c|c|}
\hline Food Name & Scientific Name & $\begin{array}{l}\text { FoodEx2 } \\
\text { TermCode }\end{array}$ & $\begin{array}{l}\text { Origin } \\
\text { (Country) }\end{array}$ & $\begin{array}{l}\text { Purchase } \\
\text { (Country) }\end{array}$ & Water $(\%)$ & Part Analysed & Colour & $\alpha$-Carotene & $\beta$-Carotene & $\beta$-Cryptoxanthin & Ref. \\
\hline Pumpkin & $\begin{array}{c}\text { Cucurbita moschata } \\
\text { Duchesne cv. Menina } \\
\text { Brasileira and cv. } \\
\text { Goianinha }\end{array}$ & $\begin{array}{c}\text { A0DLT } \\
\text { \#F20.A07QF } \\
\text { \$F20.A07RD }\end{array}$ & Brazil & & & $\begin{array}{l}\text { without skin } \\
\text { and seed }\end{array}$ & orange & 2530 & 6170 & nd & [109] \\
\hline Pumpkin & $\begin{array}{l}\text { Cucurbita moschata var. } \\
\text { Burpee Butterbush }\end{array}$ & A0DLT & Austria & Austria & & flesh fruit & & 980 & 3100 & & [152] \\
\hline Pumpkin & $\begin{array}{l}\text { Cucurbita moschata var. } \\
\text { Long Island Cheese }\end{array}$ & A0DLT & Austria & Austria & & flesh fruit & & 5900 & 7000 & & [152] \\
\hline Pumpkin & $\begin{array}{l}\text { Cucurbita moschata var. } \\
\text { Martinica }\end{array}$ & A0DLT & Austria & Austria & & flesh fruit & & 1600 & 5400 & & [152] \\
\hline Pumpkin & $\begin{array}{l}\text { Cucurbita moschata var. } \\
\text { Mousquée de Provence }\end{array}$ & A0DLT & Austria & Austria & & flesh fruit & & 2800 & 4900 & & [152] \\
\hline Pumpkin & Cucurbita pepo & $\mathrm{A} 00 \mathrm{KH}$ & Italy & Italy & & & & & 490 & 60 & [25] \\
\hline Pumpkin & Cucurbita pepo L. & $\mathrm{A} 00 \mathrm{KH}$ & Poland & Poland & 8.2 & seed and oil & $\begin{array}{l}\text { yellow- } \\
\text { green }\end{array}$ & $10-20$ & $80-210$ & $20-50$ & [153] \\
\hline Pumpkin & $\begin{array}{c}\text { Cucurbita pepo var. Acorn } \\
\text { Table }\end{array}$ & $\mathrm{A} 00 \mathrm{KH}$ & Austria & Austria & & flesh fruit & & 150 & 2100 & & [152] \\
\hline Pumpkin & $\begin{array}{c}\text { Cucurbita pepo var. Acorn } \\
\text { Tay Bell }\end{array}$ & $\mathrm{A} 00 \mathrm{KH}$ & Austria & Austria & & flesh fruit & & 150 & 2100 & & [152] \\
\hline Pumpkin & $\begin{array}{l}\text { Cucurbita pepo var. } \\
\text { Carneval di Venezia }\end{array}$ & $\mathrm{A} 00 \mathrm{KH}$ & Austria & Austria & & flesh fruit & & 30 & 60 & & [152] \\
\hline Pumpkin & $\begin{array}{c}\text { Cucurbita pepo var. } \\
\text { Melonette Jaspée Vende }\end{array}$ & $\mathrm{A} 00 \mathrm{KH}$ & Austria & Austria & & flesh fruit & & 50 & 1300 & & [152] \\
\hline Pumpkin & $\begin{array}{l}\text { Cucurbita pepo var. Tonda } \\
\text { padana (Americano) }\end{array}$ & $\mathrm{A} 00 \mathrm{KH}$ & Austria & Austria & & flesh fruit & & 120 & 2300 & & [152] \\
\hline Pumpkin & Curcubita maxima & $\mathrm{A} 00 \mathrm{KH}$ & Spain & Spain & & edible part & orange & & 490 & 60 & [24] \\
\hline Pumpkin & Curcubita maxima & $\mathrm{A} 00 \mathrm{KH}$ & Spain & Spain & & edible part & orange & 31 & 188 & & [24] \\
\hline Pumpkin & Curcubita maxima & A00KH & Spain & Spain & & edible part & orange & 53 & 692 & & [24] \\
\hline
\end{tabular}


Table A6. Rose hips and similar (A01FR) ( $\mu \mathrm{g} / 100 \mathrm{~g})$

\begin{tabular}{|c|c|c|c|c|c|c|c|c|c|c|c|c|c|c|}
\hline $\begin{array}{l}\text { Food } \\
\text { Name }\end{array}$ & $\begin{array}{l}\text { Scientific } \\
\text { Name }\end{array}$ & $\begin{array}{l}\text { FoodEx2 } \\
\text { TermCode }\end{array}$ & $\begin{array}{l}\text { FoodEx2_- } \\
\text { TermName }\end{array}$ & $\begin{array}{c}\text { Origin } \\
\text { (Country) }\end{array}$ & $\begin{array}{l}\text { Purchase } \\
\text { (Country) }\end{array}$ & $\begin{array}{c}\text { Part } \\
\text { Analysed }\end{array}$ & Colour & $\beta$-Carotene & $\begin{array}{l}E(v \text {. Trans)- } \\
\beta \text {-Carotene }\end{array}$ & $\begin{array}{l}\mathrm{Z}(\mathrm{v} \text {. cis)-B- } \\
\text { carotene }\end{array}$ & $\begin{array}{c}\text { E(v. } \\
\text { Trans)- } \beta-\end{array}$ & Phytoene & Phytofluene & Ref. \\
\hline Rosehip & Rosa canina $\mathrm{L}$. & A0DSS & Dog rose & Turkey & Turkey & $\begin{array}{l}\text { whole } \\
\text { plants }\end{array}$ & $\begin{array}{c}\text { red and } \\
\text { pink }\end{array}$ & $18-370$ & & & & & & [75] \\
\hline Rosehip & Rosa canina $\mathrm{L}$. & A0DSS & Dog rose & Germany & Germany & all sample & & $500 \pm 35$ & & & & & & [76] \\
\hline Rosehip & Rosa canina $\mathrm{L}$. & A0DSS & Dog rose & Germany & Germany & all sample & & & $290 \pm 32.5$ & & & & & [76] \\
\hline Rosehip & Rosa canina $\mathrm{L}$. & A0DSS & Dog rose & Germany & Germany & pulp & & & $3200 \pm 200$ & $500 \pm 320$ & $1200 \pm 100$ & $400 \pm 100$ & nd & [77] \\
\hline
\end{tabular}

Table A7. Rose hips and similar (A01FR) ( $\mu \mathrm{g} / 100 \mathrm{~g})$ (continuation).

\begin{tabular}{|c|c|c|c|c|c|c|c|c|c|c|c|c|c|c|}
\hline $\begin{array}{l}\text { Food } \\
\text { Name }\end{array}$ & $\begin{array}{l}\text { Scientific } \\
\text { Name }\end{array}$ & $\begin{array}{l}\text { FoodEx2 } \\
\text { TermCode }\end{array}$ & $\begin{array}{l}\text { FoodEx2 } \\
\text { TermName }\end{array}$ & $\begin{array}{l}\text { Origin } \\
\text { (Country) }\end{array}$ & $\begin{array}{l}\text { Purchase } \\
\text { (Country) }\end{array}$ & $\begin{array}{c}\text { Part } \\
\text { Analysed }\end{array}$ & Colour & Lycopene & $\begin{array}{l}\text { E(v. Trans)- } \\
\text { Lycopene }\end{array}$ & $\begin{array}{l}\text { Z(v. Cis)- } \\
\text { Lycopene }\end{array}$ & Violaxanthin & $\begin{array}{l}\text { E(v. Trans)- } \\
\text { Lutein }\end{array}$ & $\begin{array}{l}\text { E(v. Trans)- } \\
\text { Zeaxanthin }\end{array}$ & Ref. \\
\hline Rosehip & Rosa canina $\mathrm{L}$. & A0DSS & Dog rose & Germany & Germany & all sample & & $\begin{array}{c}23,842.5 \pm \\
777.5\end{array}$ & & & & & & [76] \\
\hline Rosehip & Rosa canina L. & A0DSS & Dog rose & Germany & Germany & pulp & & & $7900 \pm 1500$ & $8400 \pm 1600$ & $300 \pm 10$ & $100 \pm 10$ & $2700 \pm 30$ & [77] \\
\hline Rosehip & Rosa canina L. & A0DSS & Dog rose & Germany & Germany & pulp & & & $7400 \pm 1200$ & $6300 \pm 600$ & & $700 \pm 100$ & $600 \pm 100$ & [77] \\
\hline
\end{tabular}


Table A8. Cucurbits with inedible peel (A00KD) ( $\mu \mathrm{g} / 100 \mathrm{~g})$

\begin{tabular}{|c|c|c|c|c|c|c|c|c|c|c|c|c|c|c|c|}
\hline $\begin{array}{l}\text { Food } \\
\text { Name }\end{array}$ & Scientific Name & $\begin{array}{l}\text { FoodEx2 } \\
\text { TermCode }\end{array}$ & $\begin{array}{c}\text { Origin } \\
\text { (Country) }\end{array}$ & $\begin{array}{l}\text { Purchase } \\
\text { (Country) }\end{array}$ & $\begin{array}{c}\text { Water } \\
(\%)\end{array}$ & $\begin{array}{c}\text { Saponi- } \\
\text { Fication }\end{array}$ & $\begin{array}{c}\text { Part } \\
\text { Analysed }\end{array}$ & Colour & $\begin{array}{c}\alpha- \\
\text { Carotene }\end{array}$ & $\begin{array}{c}\beta- \\
\text { Carotene } \\
\end{array}$ & $\begin{array}{l}\text { E(v. Trans)- } \beta- \\
\text { Carotene }\end{array}$ & $\begin{array}{c}\beta- \\
\text { Cryptoxanthin } \\
\end{array}$ & Lycopene & $\begin{array}{l}\text { E(v. Trans)- } \\
\text { Lycopene }\end{array}$ & Ref. \\
\hline Watermelon & $\begin{array}{c}\text { Citrullus lanatus } \\
\text { (Thunb) Matsumura } \\
\text { \& Nakai }\end{array}$ & $\mathrm{A} 00 \mathrm{KJ}$ & Italy & Italy & & & & red & & $46-546$ & & & $959-1681$ & & {$[154]$} \\
\hline Watermelon & Citrullus lanatus & $\mathrm{A} 00 \mathrm{KJ}$ & USA & & & no & & & 0 & & 126 & 5 & & & [28] \\
\hline Watermelon & $\begin{array}{c}\text { Citrullus lanatus } \\
\text { (Thunb.) Matsum \& } \\
\text { Nakai }\end{array}$ & $\mathrm{A} 00 \mathrm{KJ}$ & Brazil & & & & & red & nd & 365 & & nd & 3550 & & [109] \\
\hline Watermelon & Citrullus vulgaris & $\begin{array}{c}\text { A00KJ } \\
\text { \#F10.A0F5H }\end{array}$ & Indonesia & & & & fruit & yellow & & $\begin{array}{c}140 \\
(56-287)\end{array}$ & & $90(59-110)$ & 71 (nd -109) & & [59] \\
\hline Watermelon & Citrullus vulgaris & $\begin{array}{c}\text { A00KJ } \\
\text { \#F10.A0F2S }\end{array}$ & Italy & Italy & & & & & nd & $314-777$ & & nd & $4770-13,523$ & & [25] \\
\hline Watermelon & Citrullus vulgaris & $\begin{array}{c}\text { A00KJ } \\
\text { \#F10.A0F5H }\end{array}$ & Italy & Italy & & & & & nd & $56-287$ & & $59-110$ & nd-109 & & [25] \\
\hline Watermelon & $\begin{array}{l}\text { Citrullus vulgaris, } \\
\text { Schered. }\end{array}$ & $\begin{array}{c}\text { A00KJ } \\
\text { \#F20.A07QF } \\
\text { \$F20.A07RD }\end{array}$ & Spain & Spain & 92 & & $\begin{array}{l}\text { without } \\
\text { rind or } \\
\text { seeds }\end{array}$ & red & & $77 \pm 29$ & & $62 \pm 20$ & $2454 \pm 319$ & & [24] \\
\hline Watermelon & Citrullus vulgaris & $\mathrm{A} 00 \mathrm{KJ}$ & Finland & Finland & & & pulp & & - & & & & & 3080 & [26] \\
\hline
\end{tabular}

Table A9. Cucurbits with inedible peel (A00KD) ( $\mu \mathrm{g} / 100 \mathrm{~g})$.

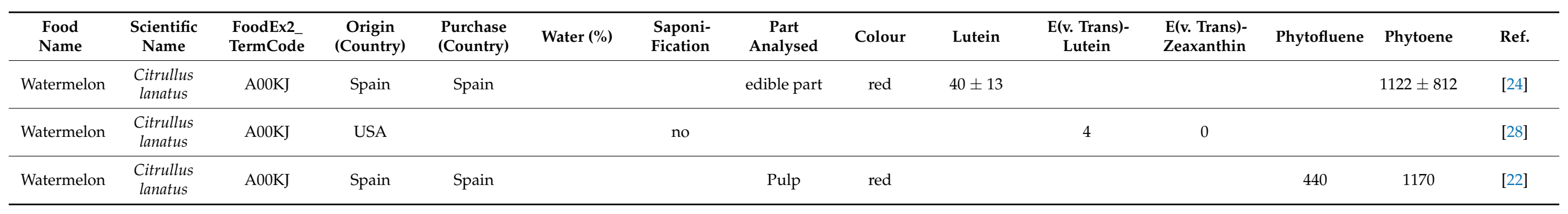




\section{References}

1. Dias, M.G.; Olmedilla-Alonso, B.; Hornero-Méndez, D.; Mercadante, A.Z.; Osorio, C.; Vargas-Murga, L.; Melendez-Martínez, A.J. Comprehensive Database of Carotenoid Contents in Ibero-American Foods. A Valuable Tool in the Context of Functional Foods and the Establishment of Recommended Intakes of Bioactives. J. Agric. Food Chem. 2018, 66, 5055-5107. [CrossRef] [PubMed]

2. Meléndez-Martínez, A.J.; Mandić, A.; Bantis, F.; Böhm, V.; Borge, G.I.; Brnčić, M.; Bysted, A.; Cano, M.P.; Dias, M.G.; Elgersma, A.; et al. A comprehensive review on carotenoids in foods and feeds: Status quo, applications, patents, and research needs. Crit. Rev. Food Sci. Nutr. 2021, 1-51. [CrossRef] [PubMed]

3. Meléndez-Martínez, A.J.; Böhm, V.; Borge, G.I.; Cano, M.P.; Fikselová, M.; Gruskiene, R.; Lavelli, V.; Loizzo, M.R.; Mandić, A.I.; Mapelli-Brahm, P.; et al. Carotenoids: Considerations for Their Use in Functional Foods, Nutraceuticals, Nutricosmetics, Supplements, Botanicals, and Novel Foods in the Context of Sustainability, Circular Economy, and Climate Change. Annu. Rev. Food Sci. Technol. 2021, 12, 433-460. [CrossRef] [PubMed]

4. European Commission; Scientific Committee on Food; European Food Safety Authority; Scientific Panel on Dietetic Products Nutrition and Allergies. Tolerable Upper Intake Levels for Vitamins and Minerals; European Food Safety Authority: Parma, Italy, 2006.

5. National Research Council (U.S.); Institute of Medicine (U.S.). Dietary Reference Intakes for Vitamin C, Vitamin E, Selenium, and Carotenoids; A Report of the Panel on Dietary Antioxidants and Related Compounds, Subcommittees on Upper Reference Levels of Nutrients and of Interpretation and Use of Dietary Reference Intakes, and the Standing Committee on the Scientific Evaluation of Dietary Reference Intakes, Food and Nutrition Board, Institute of Medicine; National Academy Press: Washington, DC, USA, 2000.

6. Buscemi, S.; Corleo, D.; Di Pace, D.; Petroni, M.L.; Satriano, A.; Marchesini, G. The Effect of Lutein on Eye and Extra-Eye Health. Nutrients 2018, 10, 1321. [CrossRef]

7. Ranard, K.; Jeon, S.; Mohn, E.; Griffiths, J.; Johnson, E.; Erdman, J. Dietary guidance for lutein: Consideration for intake recommendations is scientifically supported. Eur. J. Nutr. 2017, 56, 37-42. [CrossRef] [PubMed]

8. Regulation (EU) No 1169/2011. From: European parliament and of the council of 25 October 2011 on the provision of food information to consumers. Off. J. Eur. Union 2011, L304, 18-63.

9. IOM, Institute of Medicine of National Academies (U.S.). Panel on Micronutrients. DRI: Dietary Reference Intakes for Vitamin A, Vitamin K, Arsenic, Boron, Chromium, Copper, Iodine, Iron, Manganese, Molybdenum, Nickel, Silicon, Vanadium, and Zinc; A Report of the Institute of Medicine; Food and Nutrition Board; Panel on Micronutrients; Subcommittee on Upper Reference Levels of Nutrients; Subcommittee of Interpretation and Uses of Dietary Reference Intakes; Standing Committee on the Scientific Evaluation of Dietary Reference Intakes, Institute of Medicine; National Academy Press: Washington, DC, USA, 2001.

10. IOM, Institute of Medicine of National Academies (U.S.). Dietary Reference Intakes: The Essential Guide to Nutrient Requirements; Otten, J.J., Hellwig, J.P., Meyers, L.D., Eds.; National Academies Press: Washington, DC, USA, 2006.

11. FAO/INFOODS. Guidelines for Converting Units, Denominators and Expressions; Version 1.0; FAO: Rome, Italy, 2012.

12. Granado, F.; Olmedilla, B.; Blanco, I.; Gil-Martinez, E.; Rojas-Hidalgo, E.; Erdman, J. Variability in the intercomparison of food carotenoid content data: A user's point of view. Crit. Rev. Food Sci. Nutr. 1997, 37, 621-633. [CrossRef] [PubMed]

13. Meléndez-Martínez, A.J. An Overview of Carotenoids, Apocarotenoids, and Vitamin A in Agro-Food, Nutrition, Health, and Disease. Mol. Nutr. Food Res. 2019, 63. [CrossRef]

14. FAO. The State of the World's Biodiversity for Food and Agriculture; Bélanger, J., Pilling, D., Eds.; FAO Commission on Genetic Resources for Food and Agriculture Assessments: Rome, Italy, 2019; 572p. Available online: http://www.fao.org/3/CA3129EN/ CA3129EN.pdf (accessed on 1 February 2021).

15. Kapsokefalou, M.; Roe, M.; Turrini, A.; Costa, H.S.; Martinez-Victoria, E.; Marletta, L.; Berry Finglas, P. Food Composition at Present: New Challenges. Nutrients 2019, 11, 1714. [CrossRef]

16. Salvini, S.; Oseredczuk, M.; Roe, M.; Møller, A. Guidelines for Quality Index Attribution to Original Data from Scientific Literature or Reports for EuroFIR Data Interchange; EuroFIR Technical Report; EuroFIR AISBL: Brussels, Belgium, 2009.

17. Mangels, A.R.; Holden, J.M.; Beecher, G.R.; Forman, M.R.; Lanza, E. Carotenoid content of fruits and vegetables: An evaluation of analytic data. J. Am. Diet. Assoc. 1993, 93, 284-296. [CrossRef]

18. West, C.E.; Poortvliet, E.J. The Carotenoid Content of Foods with Special Reference to Developing Countries; Vitamin A Field Support Project (VITAL), Ed.; International Science and Technology Institute, Inc.: Arlington, VA, USA, 1993; pp. 1-207.

19. Loranty, A.; Rembiałkowska, E.; Rosa, E.A.S.; Bennett, R.N. Identification, quantification and availability of carotenoids and chlorophylls in fruit, herb and medicinal teas. J. Food Compos. Anal. 2010, 23, 432-441. [CrossRef]

20. Ireland, J.; Shahar, D.; Marletta, L.; Oyelade, O.J.; Khokhar, S.; Henauw, S. Vitamin composition of ethnic foods commonly consumed in Europe. Food Nutr. Res. 2012, 56, 1-7. [CrossRef]

21. Masino, F.; Ulrici, A.; Antonelli, A. Extraction and quantification of main pigments in pesto sauces. Eur. Food Res. Technol. 2008, 226, 569-575. [CrossRef]

22. Meléndez-Martínez, A.J.; Mapelli-Brahm, P.; Benítez-González, A.; Stinco, C.M. A comprehensive review on the colorless carotenoids phytoene and phytofluene. Arch. Biochem. Biophys. 2015, 572, 188-200. [CrossRef] [PubMed]

23. Vallverdú-Queralt, A.; de Alvarenga, J.F.R.; Estruch, R.; Lamuela-Raventos, R.M. Bioactive compounds present in the Mediterranean sofrito. Food Chem. 2013, 141, 3365-3372. [CrossRef] 
24. Beltrán, B.; Estévez, R.; Cuadrado, C.; Jiménez, S.; Olmedilla-Alonso, B. Carotenoid data base to assess dietary intake of carotenes, xanthophyls and vitamin A, its use in a comparative study of vitamin a nutritional status in young adults. Nutr. Hosp. 2012, 27, 1334-1343. [CrossRef] [PubMed]

25. Maiani, G.; Castón, M.J.; Catasta, G.; Toti, E.; Cambrodón, I.G.; Bysted, A.; Granado-Lorencio, F.; Begoña Olmedilla-Alonso, B.; Knuthsen, P.; Valoti, M.; et al. Carotenoids, actual knowledge on food sources, intakes, stability and bioavailability and their protective role in humans. Mol. Nutr. Food Res. 2009, 53 (Suppl. S2), S194-S218. [CrossRef] [PubMed]

26. Pól, J.; Hyötyläinen, T.; Ranta-Aho, O.; Riekkola, M.-L. Determination of lycopene in food by on-line SFE coupled to HPLC using a single monolithic column for trapping and separation. J. Chromatogr. A 2004, 1052, 25-31. [CrossRef]

27. Seybold, C.; Fröhlich, K.; Bitsch, R.; Otto, K.; Böhm, V. Changes in contents of carotenoids and vitamin E during tomato processing. J. Agric. Food Chem. 2004, 52, 7005-7010. [CrossRef]

28. Perry, A.; Rasmussen, H.; Johnson, E.J. Xanthophyll (lutein, zeaxanthin) content in fruits, vegetables and corn and egg products. J. Food Compos. Anal. 2009, 22, 9-15. [CrossRef]

29. Dhuique-Mayer, C.; Fanciullino, A.L.; Dubois, C.; Ollitrault, P. Effect of Genotype and Environment on Citrus Juice Carotenoid Content. J. Agric. Food Chem. 2009, 57, 9160-9168. [CrossRef] [PubMed]

30. Gama, J.J.T.; Sylos, C.M. Major carotenoid composition of Brazilian Valencia orange juice, identification and quantification by HPLC. Food Res. Int. 2005, 38, 8999-9903. [CrossRef]

31. Meléndez-Martínez, A.J.; Britton, G.; Vicario, I.M.; Heredia, F.J. The complex carotenoid pattern of orange juices from concentrate. Food Chem. 2008, 109, 546-553. [CrossRef]

32. Dias, M.G.; Camões, M.F.G.F.C.; Oliveira, L. Carotenoids in traditional Portuguese fruits and vegetables. Food Chem. 2009, 113, 808-815. [CrossRef]

33. Velázquez-Estrada, R.M.; Hernández-Herrero, M.M.; Rüfer, C.E.; Guamis-López, B.; Roig-Sagués, A.X. Influence of ultra high pressure homogenization processing on bioactive compounds and antioxidant activity of orange juice. Innov. Food Sci. Emerg. Technol. 2013, 18, 89-94. [CrossRef]

34. Fratianni, A.; Cinquanta, L.; Panfili, G. Degradation of carotenoids in orange juice during microwave heating. LWT Food Sci. Technol. 2010, 43, 867-871. [CrossRef]

35. Melendez-Martinez, A.; Vicario, I.; Heredia, F.J. A routine high-performance liquid chromatography method for carotenoid determination in ultrafrozen orange juices. J. Agric. Food Chem. 2003, 51, 4219-4224. [CrossRef] [PubMed]

36. Salvo, A.; Dugo, P.; Giuffrida, D.; Salvo, A.; Saitta, M.; Dugo, G. Free carotenoid and carotenoid ester composition in native orange juices of different varieties. Fruits 2010, 65, 277-284. [CrossRef]

37. Stinco, M.C.; Fernández-Vázquez, R.; Escudero-Gilete, M.L.; Heredia, F.J.; Meléndez-Martínez, A.J.; Vicario, M.I. Effect of orange juice's processing on the color, particle size, and bioaccessibility of carotenoids. J. Agric. Food Chem. 2012, 60, 1447-1455. [CrossRef]

38. Escudero-Lopez, B.; Cerrillo, I.; Herrero-Martín, G.; Hornero-Méndez, D.; Gil Izzquierdo, A.; Medina, S.; Ferreres, F.; Berná, G.; Medina, S.; Martín, F.; et al. Fermented Orange Juice, Source of Higher Carotenoid and Flavanone Contents. J. Agric. Food Chem. 2013, 61, 8773-8782. [CrossRef]

39. Delpino-Rius, A.; Eras, J.; Marsol-Vall, A.; Vilaró, F.; Balcells, M.; Canela-Garayoa, R. Ultraperformance liquid chromatography analysis to study the changes in the carotenoid profile of commercial monovarietal fruit juices. J. Chromatogr. A 2014, 1331, 90-99. [CrossRef]

40. La Peña, M.M.-D.; Salvia-Trujillo, L.; Rojas-Graü, M.; Martín-Belloso, O. Changes on phenolic and carotenoid composition of high intensity pulsed electric field and thermally treated fruit juice-soymilk beverages during refrigerated storage. Food Chem. 2011, 129, 982-990. [CrossRef]

41. Víctor, A.; Villanueva-Suárez, M.J.; Mateos-Aparicio, I.; Tenorio, M.D. Colour, bioactive compounds and antioxidant capacity of mixed beverages based on fruit juices with milk or soya. J. Food Nutr. Res. 2014, 53, 71-80.

42. Andrés, V.; Villanueva, M.J.; Tenorio, M.D. Simultaneous determination of tocopherols, retinol, ester derivatives and $\beta$-carotene in milk- and soy-juice based beverages by HPLC with diode-array detection. LWT Food Sci. Technol. 2014, 58, 557-562. [CrossRef]

43. Oms-Oliu, G.; Odriozola-Serrano, I.; Soliva-Fortuny, R.; Martín-Belloso, O. Effects of high-intensity pulsed electric field processing conditions on lycopene, vitamin C and antioxidant capacity of watermelon juice. Food Chem. 2009, 115, 1312-1319. [CrossRef]

44. Vallverdú-Queralt, A.; Odriozola-Serrano, I.; Oms-Oliu, G.; Lamuela-Raventós, R.M.; Elez-Martínez, P.; Martín-Belloso, O. Impact of high-intensity pulsed electric fields on carotenoids profile of tomato juice made of moderate-intensity pulsed electric field-treated tomatoes. Food Chem. 2013, 141, 3131-3138. [CrossRef]

45. Lazzerini, C.; Cifelli, M.; Domenici, V. Pigments in extra virgin olive oils produced in different mediterranean countries in 2014, Near UV-vis spectroscopy versus HPLC-DAD. LWT Food Sci. Technol. 2017, 84, 586-594. [CrossRef]

46. Mateos, R.; García-Mesa, J.A. Rapid and quantitative extraction method for the determination of chlorophylls and carotenoids in olive oil by high-performance liquid chromatography. Anal. Bioanal. Chem. 2006, 385, 1247-1249. [CrossRef] [PubMed]

47. Mapelli-Brahm, P.; Hernanz-Vila, D.; Stinco, C.M.; Heredia, F.J.; Meléndez-Martínez, A.J. Isoprenoids composition and colour to differentiate virgin olive oils from a specific mill. LWT Food Sci. Technol. 2018, 89, 18-23. [CrossRef]

48. Criado, M.N.; Morelló, J.R.; Motilva, M.J.; MPaz Romero, M.P. Effect of Growing Area on Pigment and Phenolic Fractions of Virgin Olive Oils of the Arbequina Variety in Spain. J. Am. Oil Chem. Soc. 2004, 81, 633. [CrossRef] 
49. Ernawita Wahyuono, R.; Hesse, J.; Hipler, U.-C.; Elsner, P.; Böhm, V. Carotenoids of indigenous citrus species from Aceh and its in vitro antioxidant, antidiabetic and antibacterial activities. Eur. Food Res. Technol. 2016, 242, 1869-1881. [CrossRef]

50. Fratianni, A.; Di Criscio, T.; Mignogna, R.; Panfili, G. Carotenoids, tocols and retinols evolution during egg pasta-Making processes. Food Chem. 2012, 131, 590-595. [CrossRef]

51. Zheng, H.; Zhang, Q.; Quan, J.; Zheng, Q.; Xi, W. Determination of sugars, organic acids, aroma components, and carotenoids in grapefruit pulps. Food Chem. 2016, 205, 112-121. [CrossRef]

52. Xu, C.-J.; Fraser, P.D.; Wang, W.-J.; Bramley, P.M. Differences in the Carotenoid Content of Ordinary Citrus and LycopeneAccumulating Mutants. J. Agric. Food Chem. 2006, 54, 5474-5481. [CrossRef]

53. Müller, H. Determination of the carotenoid content in selected vegetables and fruit by HPLC and photodiode array detection/Bestimmung des Carotinoidgehaltes in ausgewaehlten Gemuese-und Obstsorten mittels HPLC und Photodiodenreihenbestimmung. Z. Fuer. Leb. Und. 1997, 2, 88.

54. Lester, E.G.; Manthey, A.J.; Buslig, S.B. Organic vs. Conventionally Grown Rio Red Whole Grapefruit and Juice, Comparison of Production Inputs, Market Quality, Consumer Acceptance, and Human Health-Bioactive Compounds. J. Agric. Food Chem. 2007, 55, 4474-4480. [CrossRef] [PubMed]

55. Stinco, C.M.; Escudero-Gilete, M.L.; Heredia, F.J.; Vicario, I.M.; Meléndez-Martínez, A.J. Multivariate analyses of a wide selection of orange varieties based on carotenoid contents, color and in vitro antioxidant capacity. Food Res. Int. 2016, 90, 194-204. [CrossRef]

56. Estévez-Santiago, R.; Olmedilla-Alonso, B.; Fernández-Jalao, I. Bioaccessibility of provitamin A carotenoids from fruits, application of a standardised static in vitro digestion method. Food Funct. 2016, 7, 1354-1366. [CrossRef] [PubMed]

57. Dias, M.G.; Oliveira, L.; Camões, M.F.G.F.C.; Nunes, B.; Versloot, P.; Hulshof, P.J.M. Critical assessment of three high performance liquid chromatography analytical methods for food carotenoid quantification. J. Chromatogr. A 2010, 1217, 3494-3502. [CrossRef] [PubMed]

58. Giuffrida, D.; La Torre, L.; Manuela, S.; Pellicanò, T.M.; Dugo, G. Application of HPLC-APCI-MS with a C-30 reversed phase column for the characterization of carotenoid esters in mandarin essential oil. Flavour Fragr. J. 2006, 21, 319. [CrossRef]

59. Setiawan, B.; Sulaeman, A.; Giraud, D.W.; Driskell, J.A. Carotenoid Content of Selected Indonesian Fruits. J. Food Compos. Anal. 2001, 14, 169. [CrossRef]

60. Ruiz, D.; José Egea Tomás-Barberán, F.A.; Gil, M.I. Carotenoids from new apricot (Prunus armeniaca L.) varieties and their relationship with flesh and skin color. J. Agric. Food Chem. 2005, 53, 6368-6374. [CrossRef]

61. Sass-Kiss, A.; Kiss, J.; Milotay, P.; Kerek, M.M.; Toth-Markus, M. Differences in anthocyanin and carotenoid content of fruits and vegetables. Food Res. Int. 2005, 38, 1023-1029. [CrossRef]

62. Dragovic-Uzelac, V.; Levaj, B.; Mrkic, V.; Bursac, D.; Boras, M. The content of polyphenols and carotenoids in three apricot cultivars depending on stage of maturity and geographical region. Food Chem. 2007, 102, 966-975. [CrossRef]

63. Leccese, A.; Bureau, S.; Reich, M.; Renard, M.G.C.C.; Audergon, J.M.; Mennone, C.; Susanna Bartolini, S.; Viti, R. Pomological and Nutraceutical Properties in Apricot Fruit, Cultivation Systems and Cold Storage Fruit Management. Plant Foods Hum. Nutr. 2010, 65, 112-120. [CrossRef]

64. De Rigal, D.; Gauillard, F.; Richard-Forget, F. Changes in the carotenoid content of apricot (Prunus armeniaca, var Bergeron) during enzymatic browning, $\beta$-carotene inhibition of chlorogenic acid degradation. J. Sci. Food Agric. 2000, 80, 763-768. [CrossRef]

65. Orazem, P.; Mikulic-Petkovsek, M.; Stampar, F.; Hudina, M. Changes during the last ripening stage in pomological and biochemical parameters of the 'Redhaven' peach cultivar grafted on different rootstocks. Sci. Hortic. 2013, 160, 326-334. [CrossRef]

66. Lozzio, M.R.; Pacetti, D.; Lucci, P.; Núñez, O.; Menichini, F.; Frega, N.G.; Tundis, R. Prunus persica var. platycarpa (Tabacchiera Peach), Bioactive Compounds and Antioxidant Activity of Pulp, Peel and Seed Ethanolic Extracts. Plant Foods Hum. Nutr. 2015, 70, 331-337. [CrossRef] [PubMed]

67. Crupi, P.; Coletta, A.; Antonacci, D. Analysis of Carotenoids in Grapes to Predict Norisoprenoid Varietal Aroma of Wines from Apulia. J. Agric. Food Chem. 2010, 58, 9647-9656. [CrossRef]

68. Mendes-Pinto, M.M.; Ferreira, A.C.S.; Caris-Veyrat, C.; de Pinho, P.G. Carotenoid, chlorophyll, and chlorophyll-derived compounds in grapes and Port wines. J. Agric. Food Chem. 2005, 53, 10034-10041. [CrossRef]

69. Giovanelli, G.; Brenna, O.V. Evolution of some phenolic components, carotenoids and chlorophylls during ripening of three Italian grape varieties. Z. Leb. Und. Forsch. A Eur. Food Res. Technol. 2007, 225, 145-150. [CrossRef]

70. Leontowicz, H.; Leontowicz, M.; Latocha, P.; Jesion, I.; Park, Y.S.; Katrich, E.; Barasch, D.; Nemirovski, A.; Gorinstein, S. Bioactivity and nutritional properties of hardy kiwi fruit Actinidia arguta in comparison with Actinidia deliciosa "Hayward" and Actinidia eriantha "Bidan". Food Chem. 2016, 196, 281-291. [CrossRef] [PubMed]

71. Marinova, D.; Ribarova, F. HPLC determination of carotenoids in Bulgarian berries. J. Food Compos. Anal. 2007, 20, 370-374 [CrossRef]

72. Carvalho, E.; Fraser, P.D.; Martens, S. Carotenoids and tocopherols in yellow and red raspberries. Food Chem. 2013, 139, 744-752. [CrossRef]

73. Karppinen, K.; Zoratti, L.; Sarala, M.; Carvalho, E.; Hirsimaki, J.; Mentula, H.; Martens, S.; Häggman, H.; Jaakola, L. Carotenoid metabolism during bilberry (Vaccinium myrtillus L.) fruit development under different light conditions is regulated by biosynthesis and degradation. BMC Plant Biol. 2016, 16, 95. [CrossRef] 
74. Mihalcea, L.; Turturică, M.; Ghinea, I.O.; Barbu, V.; Ioniţă, E.; Cotârleț, M.; Stănciuc, N. Encapsulation of carotenoids from sea buckthorn extracted by CO2 supercritical fluids method within whey proteins isolates matrices. Innov. Food Sci. Emerg. Technol. 2017, 42, 120-129. [CrossRef]

75. Kazaz, S.; Baydar, H.; Erbas, S. Variations in chemical compositions of Rosa damascena Mill. and Rosa canina L. fruits. Czech J. Food Sci. 2009, 27, 178-184. [CrossRef]

76. Böhm, V.; Fröhlich, K.; Bitsch, R. Rosehip-A “new” source of lycopene? Mol. Asp. Med. 2003, 24, 385-389. [CrossRef]

77. Al-Yafeai, A.; Malarski, A.; Böhm, V. Characterization of carotenoids and vitamin E in R. rugosa and R. canina, Comparative analysis. Food Chem. 2018, 242, 435-442. [CrossRef]

78. Lachowicz, S.; Oszmiański, J.; Pluta, S. The composition of bioactive compounds and antioxidant activity of Saskatoon berry (Amelanchier alnifolia Nutt.) genotypes grown in central Poland. Food Chem. 2017, 235, 234-243. [CrossRef]

79. Delgado-Pelayo, R.; Hornero-Mendez, D. Identification and Quantitative Analysis of Carotenoids and Their Esters from Sarsaparilla (Smilax aspera L.) Berries. J. Agric. Food Chem. 2012, 60, 8225-8232. [CrossRef] [PubMed]

80. Khoo, H.E.; Ismail, A.; Mohd-Esa, N.; Idris, S. Carotenoid Content of Underutilized Tropical Fruits. Plant Foods Hum. Nutr. 2008, 63, 170-175. [CrossRef]

81. Yemiş, O.; Bakkalbaşı, E.; Artık, N. Changes in pigment profile and surface colour of fig (Ficus carica L.) during drying. Int. J. Food Sci. Technol. 2012, 47, 1710-1719. [CrossRef]

82. Plaza, L.; Colina, C.; Ancos B de Sánchez-Moreno, C.; Pilar Cano, M. Influence of ripening and astringency on carotenoid content of high-pressure treated persimmon fruit (Diospyros kaki L.). Food Chem. 2012, 130, 591-597. [CrossRef]

83. Veberic, R.; Jurhar, J.; Mikulic-Petkovsek, M.; Stampar, F.; Schmitzer, V. Comparative study of primary and secondary metabolites in 11 cultivars of persimmon fruit (Diospyros kaki L.). Food Chem. 2010, 119, 477-483. [CrossRef]

84. Ribeiro, P.F.A.; Stringheta, P.C.; de Oliveira, E.B.; Mendonca, A.C.; Sant'Ana, H.M.P. Levels of vitamin C, beta.-carotene and minerals in camu-camu cultivated in different environments/Teor de vitamina $C$, beta.-caroteno e minerais em camu-camu cultivado em diferentes ambientes. Cienc. Rural 2016, 46, 567-572. [CrossRef]

85. Delgado-Pelayo, R.; Gallardo-Guerrero, L.; Hornero-Méndez, D. Carotenoid composition of strawberry tree (Arbutus unedo L.) fruits. Food Chem. 2016, 199, 165-175. [CrossRef] [PubMed]

86. Rodriguez-Amaya, D.B. Some considerations in generating carotenoid data for food composition tables. J. Food Compos. Anal. 2000, 13, 641-647. [CrossRef]

87. Mezadri, T.; Villaño, D.; Fernández-Pachón, M.S.; García-Parrilla, M.C.; Troncoso, A.M. Antioxidant compounds and antioxidant activity in acerola (Malpighia emarginata DC.) fruits and derivatives. J. Food Compos. Anal. 2008, 21, 282-290. [CrossRef]

88. D’Evoli, L.; Moscatello, S.; Lucarini, M.; Aguzzi, A.; Gabrielli, P.; Proietti, S.; Battistelli, A.; Famiani, F.; Böhm, V.; Lombardi-Boccia, G. Nutritional traits and antioxidant capacity of kiwifruit (Actinidia deliciosa Planch., cv. Hayward) grown in Italy. J. Food Compos. Anal. 2015, 37, 25-29. [CrossRef]

89. Englberger, L.; Wills, R.B.H.; Blades, B.; Dufficy, L.; Daniells, J.W.; Coyne, T. Carotenoid content and flesh color of selected banana cultivars growing in Australia. Food Nutr. Bull. 2006, 27, 281-291. [CrossRef] [PubMed]

90. Ekesa, B.; Nabuuma, D.; Blomme, G.; van den Bergh, I. Provitamin A carotenoid content of unripe and ripe banana cultivars for potential adoption in eastern Africa. J. Food Compos. Anal. 2015, 43, 1-6. [CrossRef]

91. García-Herrera, P.; Sánchez-Mata, M.C.; Cámara, M.; Tardío, J.; Olmedilla-Alonso, B. Carotenoid content of wild edible young shoots traditionally consumed in Spain (Asparagus acutifolius L., Humulus lupulus L., Bryonia dioica Jacq. and Tamus communis L.). J. Sci. Food Agric. 2013, 93, 1692-1698, Erratum in J. Sci. Food Agric. 2014, 94, 1914-1916. [CrossRef] [PubMed]

92. Mertz, C.; Gancel, A.-L.; Gunata, Z.; Alter, P.; Dhuique-Mayer, C.; Vaillant, F.; Perez, A.M.; Ruales, J.; Brat, P. Phenolic compounds, carotenoids and antioxidant activity of three tropical fruits. J. Food Compos. Anal. 2009, 22, 381-387. [CrossRef]

93. Mertz, C.; Brat, P.; Caris-Veyrat, C.; Gunata, Z. Characterization and thermal lability of carotenoids and vitamin C of tamarillo fruit (Solanum betaceum Cav.). Food Chem. 2010, 119, 653-659. [CrossRef]

94. Kornsteiner, M.; Wagner, K.H.; Elmadfa, I. Tocopherols and total phenolics in 10 different nut types. Food Chem. 2006, 98, 381-387. [CrossRef]

95. Burns, J.; Fraser, P.D.; Bramley, P.M. Identification and quantification of carotenoids, tocopherols and chlorophylls in commonly consumed fruits and vegetables. Phytochemistry 2003, 62, 939-947. [CrossRef]

96. Fattore, M.; Montesano, D.; Pagano, E.; Teta, R.; Borrelli, F.; Mangoni, A.; Seccia, S.; Albrizio, S. Carotenoid and flavonoid profile and antioxidant activity in "Pomodorino Vesuviano" tomatoes. J. Food Compos. Anal. 2016, 53, 61-68. [CrossRef]

97. Znidarčič, D.; Ban, D.; Sircelj, H. Carotenoid and chlorophyll composition of commonly consumed leafy vegetables in Mediterranean countries. Food Chem. 2011, 129, 1164-1168. [CrossRef]

98. Raju, M.; Varakumar, S.; Lakshminarayana, R.; Krishnakantha, T.P.; Baskaran, V. Carotenoid composition and vitamin A activity of medicinally important green leafy vegetables. Food Chem. 2007, 101, 1598-1605. [CrossRef]

99. Burgos, G.; Muñoa, L.; Sosa, P.; Bonierbale, M.; zum Felde, T.; Díaz, C. In vitro bioaccessibility of lutein and zeaxanthin of yellow fleshed boiled potatoes. Plant Foods Hum. Nutr. 2013, 68, 385-390. [CrossRef] [PubMed]

100. Champagne, A.; Bernillon, S.; Moing, A.; Rolin, D.; Legendre, L.; Lebot, V. Carotenoid profiling of tropical root crop chemotypes from Vanuatu, South Pacific. J. Food Compos. Anal. 2010, 23, 763-771. [CrossRef] 
101. López, A.; Javier, G.-A.; Fenoll, J.; Hellín, P.; Flores, P. Original Research Article, Chemical composition and antioxidant capacity of lettuce, Comparative study of regular-sized (Romaine) and baby-sized (Little Gem and Mini Romaine) types. J. Food Compos. Anal. 2014, 33, 39-48. [CrossRef]

102. Fernández-Marín, B.; Míguez, F.; Méndez-Fernández, L.; Agut, A.; Becerril, J.M.; García-Plazaola, J.I.; Kranner, I.; Colville, L. Seed Carotenoid and Tocochromanol Composition of Wild Fabaceae Species Is Shaped by Phylogeny and Ecological Factors. Front. Plant. Sci. 2017, 8, 1428. [CrossRef]

103. Kim, H.-J.; Fonseca, J.M.; Choi, J.-H.; Kubota, C.; Kwon, D.Y. Salt in irrigation water affects the nutritional and visual properties of romaine lettuce (Lactuca sativa L.). J. Agric. Food Chem. 2008, 56, 3772-3776. [CrossRef] [PubMed]

104. Brazaitytè, A.; Sakalauskienè, S.; Samuolienè, G.; Jankauskienè, J.; Viršilè, A.; Novičkovas, A.; Sirtautas, R.; Miliauskienė, J.; Vaštakaite, V.; Dabašinskas, L.; et al. The effects of LED illumination spectra and intensity on carotenoid content in Brassicaceae microgreens. Food Chem. 2015, 173, 600-606. [CrossRef]

105. Bengtsson, A.; Namutebi, A.; Alminger, M.L.; Svanberg, U. Effects of various traditional processing methods on the all-trans- $\beta$ carotene content of orange-fleshed sweet potato. J. Food Compos. Anal. 2008, 21, 134-143. [CrossRef]

106. Hels, O.; Larsen, T.; Christensen, L.P.; Kidmose, U.; Hassan, N.; Thilsted, S.H. Contents of iron, calcium, zinc and $\beta$-carotene in commonly consumed vegetables in Bangladesh. J. Food Compos. Anal. 2004, 17, 587-595. [CrossRef]

107. Fernandez-Orozco, R.; Gallardo-Guerrero, L.; Hornero-Méndez, D. Carotenoid profiling in tubers of different potato (Solanum sp.) cultivars, Accumulation of carotenoids mediated by xanthophyll esterification. Food Chem. 2013, 141, 2864-2872. [CrossRef]

108. Mosha, T.; Pace, R.; Adeyeye, S.; Laswai, H.; Mtebe, K. Effect of traditional processing practices on the content of total carotenoid, $\beta$-carotene, $\alpha$-carotene and vitamin A activity of selected Tanzanian vegetables. Plant Foods Hum. Nutr. 1997, 50, 189-201. [CrossRef]

109. Vargas-Murga, L.; de Rosso, V.V.; Mercadante, A.Z.; Olmedilla-Alonso, B. Fruits and vegetables in the Brazilian Household Budget Survey (2008-2009), carotenoid content and assessment of individual carotenoid intake. J. Food Compos. Anal. 2016, 50, 88-96. [CrossRef]

110. Samuolienè, G.; Viršilè, A.; Brazaitytè, A.; Jankauskienè, J.; Sakalauskienė, S.; Vaštakaitè, V.; Novičkovas, A.; Viškelienėa, A.; Sasnauskasa, A.; Duchovskis, P. Blue light dosage affects carotenoids and tocopherols in microgreens. Food Chem. 2017, 228, 50-56. [CrossRef] [PubMed]

111. Mazzeo, T.; N’Dri, D.; Chiavaro, E.; Visconti, A.; Fogliano, V.; Pellegrini, N. Effect of two cooking procedures on phytochemical compounds, total antioxidant capacity and colour of selected frozen vegetables. Food Chem. 2011, 128, 627-633. [CrossRef]

112. Duma, M.; Alsina, I.; Zeipina, S.; Dubova, L. Leaf vegetables as source of phytochemicals. In Proceedings of the 9th Baltic Conference on Food Science and Technology "Food for Consumer Well-Being" (FOODBALT 2014), Jelgava, Latvia, 8-9 May 2014.

113. Arnold, C.; Schwarzenbolz, U.; Bohm, V. Carotenoids and chlorophylls in processed xanthophyll-rich food. LWT Food Sci. Technol. 2014, 57, 442. [CrossRef]

114. Simonovska, B.; Vovk, I.; Glavnik, V.; Černelič, K. Effects of extraction and high-performance liquid chromatographic conditions on the determination of lutein in spinach. J. Chromatogr. A 2013, 1276, 95-101. [CrossRef]

115. Appenroth, K.-J.; Sree, K.S.; Böhm, V.; Hammann, S.; Vetter, W.; Leiterer, M.; Jahreis, G. Nutritional value of duckweeds (Lemnaceae) as human food. Food Chem. 2017, 217, 266-273. [CrossRef]

116. Lalas, S.; Athanasiadis, V.; Karageorgou, I.; Batra, G.; Nanos, G.D.; Makris, D.P. Nutritional Characterization of Leaves and Herbal Tea of Moringa oleifera Cultivated in Greece. J. Herbs Spices Med. Plants 2017, 23, 320-333. [CrossRef]

117. Abbet, C.; Slacanin, I.; Hamburger, M.; Potterat, O. Comprehensive analysis of Phyteuma orbiculare L., a wild Alpine food plant. Food Chem. 2013, 136, 595-603. [CrossRef]

118. Pellegrini, N.; Chiavaro, E.; Gardana, C.; Mazzeo, T.; Contino, D.; Gallo, M.; Riso, P.; Fogliano, V.; Porrini, M. Effect of Different Cooking Methods on Color, Phytochemical Concentration, and Antioxidant Capacity of Raw and Frozen Brassica Vegetables. J. Agric. Food Chem. 2010, 58, 4310-4321. [CrossRef] [PubMed]

119. Campos, F.M.; Chaves, J.B.P.; de Azeredo, P.M. Handling Practices to Control Ascorbic Acid and $\beta$-Carotene Losses in Collards (Brassica oleracea). Food Sci. Technol. Int. 2010, 15, 445-452. [CrossRef]

120. Arnold, C.; Jentsch, S.; Dawczynski, J.; Bohm, V. Age-related macular degeneration, Effects of a short-term intervention with an oleaginous kale extract-A pilot study. Nutrition 2013, 29, 1412-1417. [CrossRef]

121. Santos, J.; Herrero, M.; Mendiola, J.A.; Oliva-Teles, M.T.; Ibáñez, E.; Delerue-Matos, C.; Oliveira, M.B.P.P. Assessment of nutritional and metabolic profiles of pea shoots, the new ready-to-eat baby-leaf vegetable. Food Res. Int. 2014, 58, 105-111. [CrossRef]

122. Granado-Lorencio, F.; Olmedilla-Alonso, B.; Herrero-Barbudo, C.; Sánchez-Moreno, C.; de Ancos, B.; Martínez, J.A.; PérezSacristán, B.; Blanco-Navarro, I. Modified-atmosphere packaging (MAP) does not affect the bioavailability of tocopherols and carotenoids from broccoli in humans, A cross-over study. Food Chem. 2008, 106, 1070-1076. [CrossRef]

123. Fernández-León, M.F.; Fernández-León, A.M.; Lozano, M.; Ayuso, M.C.; González-Gómez, D. Altered commercial controlled atmosphere storage conditions for 'Parhenon' broccoli plants (Brassica oleracea L. var. italica). Influence on the outer quality parameters and on the health-promoting compounds. LWT Food Sci. Technol. 2013, 50, 665-672. [CrossRef]

124. Guil-Guerrero, J.L.; Rebolloso-Fuentes, M.M. Nutrient composition and antioxidant activity of eight tomato (Lycopersicon esculentum) varieties. J. Food Compos. Anal. 2009, 22, 123-129. [CrossRef]

125. Dias, M.G.; Camões, M.F.G.F.C.; Oliveira, L. Uncertainty estimation and in-house method validation of HPLC analysis of carotenoids for food composition data production. Food Chem. 2008, 109, 815-824. [CrossRef] 
126. Krauss, S.; Schnitzler, W.H.; Grassmann, J.; Woitke, M. The influence of different electrical conductivity values in a simplified recirculating soilless system on inner and outer fruit quality characteristics of tomato. J. Agric. Food Chem. 2006, 54, 441-448. [CrossRef] [PubMed]

127. De Pascale, S.; Maggio, A.; Fogliano, V.; Ambrosino, P.; Ritieni, A. Irrigation with saline water improves carotenoids content and antioxidant activity of tomato. J. Hortic. Sci. BioTechnol. 2001, 76, 447-453. [CrossRef]

128. D'Antuono, L.F.; Elementi, S.; Neri, R. Genotype x environment interaction on carrot germplasm Daucus carota L., Emilia-Romagna. Italus Hortus 2006, 13, 693-697.

129. Patanè, C.; Pellegrino, A.; Saita, A.; Siracusa, L.; Ruberto, G.; Barbagallo, R. Mediterranean long storage tomato as a source of novel products for the agrifood industry, Nutritional and technological traits. LWT Food Sci. Technol. 2017, 85, 445-448. [CrossRef]

130. Lahoz, I.; Leiva-Brondo, M.; Martí, R.; Macua, J.I.; Campillo, C.; Roselló, S.; Cebolla-Cornejo, J. Influence of high lycopene varieties and organic farming on the production and quality of processing tomato. Sci. Hortic. 2016, 204, 128-137. [CrossRef]

131. Aherne, A.; Jiwan, M.; Daly, T.; O’Brien, N. Geographical Location has Greater Impact on Carotenoid Content and Bioaccessibility from Tomatoes than Variety. Plant Foods Hum. Nutr. 2009, 64, 250-256. [CrossRef] [PubMed]

132. Gautier, H.; Diakou-Verdin, V.; Bénard, C.; Reich, M.; Buret, M.; Bourgaud, F.; Poëssel, J.C.; Caris-Veyrat, C.; Génard, M. How does tomato quality (sugar, acid, and nutritional quality) vary with ripening stage, temperature, and irradiance? J. Agric. Food Chem. 2008, 56, 1241-1250. [CrossRef] [PubMed]

133. Gautier, H.; Rocci, A.; Buret, M.; Grasselly, D.; Dumas, Y.; Causse, M. Effect of photoselective filters on the physical and chemical traits of vine-ripened tomato fruits. Can. J. Plant. Sci. 2005, 85, 439-446. [CrossRef]

134. Borghesi, E.; González-Miret, M.L.; Escudero-Gilete, M.L.; Malorgio, F.; Heredia, F.J.; Meléndez-Martínez, A.J. Effects of Salinity Stress on Carotenoids, Anthocyanins, and Color of Diverse Tomato Genotypes. J. Agric. Food Chem. 2011, 59, 11676-11682. [CrossRef] [PubMed]

135. Vallverdú-Queralt, A.; Oms-Oliu, G.; Odriozola-Serrano, I.; Lamuela-Raventós, R.M.; Martín-Belloso, O.; Elez-Martínez, P. Metabolite profiling of phenolic and carotenoid contents in tomatoes after moderate-intensity pulsed electric field treatments. Food Chem. 2013, 136, 199-205. [CrossRef]

136. Strati, I.F.; Sinanoglou, V.J.; Kora, L.; Miniadis-Meimaroglou, S.; Oreopoulou, V. Carotenoids from Foods of Plant, Animal and Marine Origin, An Efficient HPLC-DAD Separation Method. Foods 2012, 1, 52-65. [CrossRef]

137. Hernández, V.; Hellín, P.; Fenoll, J.; Flores, P. Increased temperature produces changes in the bioactive composition of tomato, depending on its developmental stage. J. Agric. Food Chem. 2015, 63, 2378-2382. [CrossRef]

138. Colle, I.; Lemmens, L.; van Buggenhout, S.; van Loey, A.; Hendrickx, M. Effect of Thermal Processing on the Degradation, Isomerization, and Bioaccessibility of Lycopene in Tomato Pulp. J. Food Sci. 2010, 75, C753-C758. [CrossRef]

139. Efthimiadou, A.; Katsenios, N.; Karkanis, A.; Papastylianou, P.; Triantafyllidis, V.; Travlos, I.; Bilalis, D.M. Effects of presowing pulsed electromagnetic treatment of tomato seed on growth, yield, and lycopene content. Sci. World J. 2014. [CrossRef]

140. Stinco, C.M.; Rodríguez-Pulido, F.J.; Escudero-Gilete, M.L.; Gordillo, B.; Vicario, I.M.; Meléndez-Martínez, A.J. Lycopene isomers in fresh and processed tomato products, correlations with instrumental color measurements by digital image analysis and spectroradiometry. Food Res. Int. 2013, 50, 111-120. [CrossRef]

141. Coyago-Cruz, E.; Corell, M.; Stinco, C.M.; Hernanz, D.; Moriana, A.; Meléndez-Martínez, A.J. Effect of regulated deficit irrigation and cluster position on quality parameters, carotenoids and phenolics of diverse tomato varieties (Solanum lycopersicum L.). Food Res. Int. 2017, 9, 72-83. [CrossRef] [PubMed]

142. Pugliese, A.; O'Callaghan, Y.; Tundis, R.; Galvin, K.; Menichini, F.; O’Brien, N.; Loizzo, M.R. In vitro investigation of the bioaccessibility of carotenoids from raw, frozen and boiled red chili peppers (Capsicum annuum). Eur. J. Nutr. 2014, 53, 501-510. [CrossRef]

143. Giuffrida, D.; Dugo, P.; Torre, G.; Bignardi, C.; Cavazza, A.; Corradini, C.; Dugo, G. Characterization of 12 Capsicum varieties by evaluation of their carotenoid profile and pungency determination. Food Chem. 2013, 140, 794-802. [CrossRef] [PubMed]

144. Rodríguez-Burruezo, A.; del Carmen González-Mas, M.; Nuez, F. Carotenoid Composition and Vitamin A Value in Ají (Capsicum baccatum L.) and Rocoto (C. pubescens R. \& P.), 2 Pepper Species from the Andean Region. J. Food Sci. 2010, 75, S44-S53. [CrossRef]

145. Topuz, A.; Ozdemir, F. Assessment of carotenoids, capsaicinoids and ascorbic acid composition of some selected pepper cultivars (Capsicum annuum L.) grown in Turkey. J. Food Compos. Anal. 2007, 20, 596-602. [CrossRef]

146. Molnár, H.; Bata-Vidács, I.; Baka, E.; Cserhalmi, Z.; Ferenczi, S.; Tömösközi-Farkas, R.; Adányi, N.; Székács, A. The effect of different decontamination methods on the microbial load, bioactive components, aroma and colour of spice paprika. Food Control. 2018, 83, 131-140. [CrossRef]

147. Simonne, A.H.; Simonne, E.H.; Eitenmiller, R.R.; Mills, H.A.; Green, N.R. Ascorbic Acid and Provitamin A Contents in Unusually Colored Bell Peppers (Capsicum annuum L.). J. Food Compos. Anal. 1997, 10, 299-311. [CrossRef]

148. Hornero-Méndez, D.; Costa-García, J.; Mínguez-Mosquera, M.I. Characterization of carotenoid high-producing Capsicum annuum cultivars selected for paprika production. J. Agric. Food Chem. 2002, 50, 5711-5716. [CrossRef]

149. Minguez-Mosquera, M.I.; Hornero-Mendez, D. Separation and quantification of the carotenoid pigments in red peppers (Capsicum annuum L.), paprika, and oleoresin by reversed-phase HPLC. J. Agric. Food Chem. 1993, 41, 1616-1620. [CrossRef]

150. Tran, X.T.; Parks, S.E.; Roach, P.D.; Golding, J.B.; Nguyen, M.H. Effects of maturity on physicochemical properties of Gac fruit (Momordica cochinchinensis Spreng). Food Sci. Nutr. 2016, 4, 305. [CrossRef] 
151. Conti, S.; Villari, G.; Amico, E.; Caruso, G. Effects of production system and transplanting time on yield, quality and antioxidant content of organic winter squash (Cucurbita moschata Duch.). Sci. Hortic. 2015, 183, 136-143. [CrossRef]

152. Murkovic, M.; Mülleder, U.; Neunteufl, H. Carotenoid Content in Different Varieties of Pumpkins. J. Food Compos. Anal. 2002, 15, 633-638. [CrossRef]

153. Raczyk, M.; Siger, A.; Radziejewska-Kubzdela, E.; Ratusz, K.; Rudzińska, M. Roasting pumpkin seeds and changes in the composition and oxidative stability of cold-pressed oils. Acta Sci. Pol. Technol. Aliment. 2017, 16, 293-301. [CrossRef] [PubMed]

154. Bianchi, G.; Rizzolo, A.; Grassi, M.; Provenzi, L.; Lo Scalzo, R. External maturity indicators, carotenoid and sugar compositions and volatile patterns in 'Cuoredolce ${ }^{\circledR \prime}$ and 'Rugby' mini-watermelon (Citrullus lanatus (Thunb) Matsumura \& Nakai) varieties in relation of ripening degree at harvest. Postharvest Biol. Technol. 2018, 136, 1-11. [CrossRef]

155. Kurilich, A.; Juvik, J. Simultaneous quantification of carotenoids and tocopherols in corn kernel extracts by HPLC. J. Liq. Chromatogr. Relat. Technol. 1999, 22, 2925-2934. [CrossRef]

156. Bozalan, N.K.; Karadeniz, F. Carotenoid Profile, Total Phenolic Content, and Antioxidant Activity of Carrots. Int. J. Food Prop. 2011, 14, 1060-1068. [CrossRef]

157. Borowska, J.E.; Zadernowski, R.; Szajdek, A.; Majewska, K.; Budrewicz, G. Organoleptic, physical and chemical properties of some varieties of carrots suitable in juice production. Pol. J. Nat. Sci. 2005, 18, 173-186.

158. Aguiló-Aguayo, I.; Gangopadhyay, N.; Lyng, J.G.; Brunton, N.; Rai, D.K. Impact of pulsed light on colour, carotenoid, polyacetylene and sugar content of carrot slices. Innov. Food Sci. Emerg. Technol. 2017, 42, 49-55. [CrossRef]

159. Nicolle, C.; Simon, G.; Rock, E.; Amouroux, P.; Rémésy, C. Genetic Variability Influences Carotenoid, Vitamin Phenolic, and Mineral Content in White, Yellow, Purple, Orange, and Dark-orange Carrot Cultivars. J. Am. Soc. Hortic. Sci. 2004, 129, 523-529. [CrossRef]

160. Koca, N. Carotenoids and Antioxidant Activity in Carrots (Daucus carota L.)/Havuçlarda (Daucus carota L.) Karotenoidler ve Antioksidan Aktivite. Ph.D. Thesis, Ankara University, Ankara, Turkey, 2006; 81p.

161. Rosenfeld, H.J.; Baardseth, P.; Skrede, G. Evaluation of carrot varieties for production of deep fried carrot chips-IV. The influence of growing environment on carrot raw material. Food Res. Int. 1997, 30, 611-618. [CrossRef]

162. Herrero, M.; Jaime, L.; Martín-Alvarez, P.J.; Cifuentes, A.; Ibáñez, E. Optimization of the extraction of antioxidants from Dunaliella salina microalga by pressurized liquids. J. Agric. Food Chem. 2006, 54, 5597-5603. [CrossRef] [PubMed]

163. Jaeschke, D.P.; Menegol, T.; Rech, R.; Mercali, G.D.; Marczak, L.D.F. Carotenoid and lipid extraction from Heterochlorella luteoviridis using moderate electric field and ethanol. Process. BioChem. 2016, 51, 1636-1643. [CrossRef]

164. Castro-Puyana, M.; Herrero, M.; Urreta, I.; Mendiola, J.A.; Cifuentes, A.; Ibanez, E.; Suárez-Alvarez, S. Optimization of clean extraction methods to isolate carotenoids from the microalga Neochloris oleoabundans and subsequent chemical characterization using liquid chromatography tandem mass spectrometry. Anal. Bioanal. Chem. 2013, 13, 4607-4616. [CrossRef] [PubMed]

165. Al-Duais, M.; Hohbein, J.; Werner, S.; Böhm, V.; Jetschke, G. Contents of vitamin C, carotenoids, tocopherols, and tocotrienols in the subtropical plant species Cyphostemma digitatum as affected by processing. J. Agric. Food Chem. 2009, 57, 5420-5427. [CrossRef]

166. Knockaert, G.; Lemmens, L.; van Buggenhout, S.; Hendrickx, M.; van Loey, A. Changes in $\beta$-carotene bioaccessibility and concentration during processing of carrot puree. Food Chem. 2012, 133, 60-67. [CrossRef]

167. Valdivielso, I.; Bustamante, M.A.; de Gordoa, J.C.R.; Nájera, A.I.; Renobales, M.; Barron, L.J.R. Simultaneous analysis of carotenoids and tocopherols in botanical species using one step solid liquid extraction followed by high performance liquid chromatography. Food Chem. 2015, 15, 709-717. [CrossRef]

168. Lenucci, M.S.; de Caroli, M.; Marrese, P.P.; Iurlaro, A.; Rescio, L.; Böhm, V.; Dalessandro, G.; Piro, G. Enzyme-aided extraction of lycopene from high-pigment tomato cultivars by supercritical carbon dioxide. Food Chem. 2015, 170, 193-202. [CrossRef]

169. Gámez, M.C.; Calvo, M.M.; Selgas, M.D.; García, M.L.; Erler, K.; Böhm, V.; Catalano, A.; Simone, R.; Palozza, P. Effect of E-beam treatment on the chemistry and on the antioxidant activity of lycopene from dry tomato peel and tomato powder. J. Agric. Food Chem. 2014, 62, 1557-1563. [CrossRef]

170. Paznocht, L.; Kotíková, Z.; Šulc, M.; Lachman, J.; Orsák, M.; Eliášová, M.; Martinek, P. Free and esterified carotenoids in pigmented wheat, tritordeum and barley grains. Food Chem. 2018, 240, 670-678. [CrossRef] [PubMed]

171. Brandolini, A.; Hidalgo, A.; Gabriele, S.; Heun, M. Chemical composition of wild and feral diploid wheats and their bearing on domesticated wheats. J. Cereal Sci. 2015, 63, 122-127. [CrossRef]

172. Hidalgo, A.; Brandolini, A. Nitrogen fertilisation effects on technological parameters and carotenoid, tocol and phenolic acid content of einkorn (Triticum monococcum L. subsp. monococcum), a two-year evaluation. J. Cereal Sci. 2017, 73, 18-24. [CrossRef]

173. Hidalgo, A.; Scuppa, S.; Brandolini, A. Technological quality and chemical composition of puffed grains from einkorn (Triticum monococcum L. subsp. monococcum) and bread wheat (Triticum aestivum L. subsp. aestivum). LWT Food Sci. Technol. 2016, 68, 541-548. [CrossRef]

174. Kljak, K.; Grbeša, D. Carotenoid content and antioxidant activity of hexane extracts from selected Croatian corn hybrids. Food Chem. 2015, 167, 402-408. [CrossRef] [PubMed]

175. Hulshof, P.J.M.; Kosmeijer-Schuil, T.; West, C.E.; Hollman, P.C.H. Quick screening of maize kernels for provitamin A content. J. Food Compos. Anal. 2007, 20, 655-661. [CrossRef]

176. Pereira-Caro, G.; Cros, G.; Yokota, T.; Crozier, A. Phytochemical Profiles of Black, Red, Brown, and White Rice from the Camargue Region of France. J. Agric. Food Chem. 2013, 61, 7976-7986. [CrossRef] 
177. Atienza, S.G.; Ballesteros, J.; Martín, A.; Hornero-Méndez, D. Genetic variability of carotenoid concentration and degree of esterification among tritordeum (xTritordeum Ascherson et Graebner) and durum wheat accessions. J. Agric. Food Chem. 2007, 55, 4244-4251. [CrossRef]

178. Ziegler, J.U.; Schweiggert, R.M.; Carle, R. A method for the simultaneous extraction and quantitation of lipophilic antioxidants in Triticum sp. by HPLC-DAD/FLD-MSn. J. Food Compos. Anal. 2015, 39, 94-102. [CrossRef]

179. Hidalgo, A.; Brandolini, A.; Pompei, C. Carotenoids evolution during pasta, bread and water biscuit preparation from wheat flours. Food Chem. 2010, 121, 746-751. [CrossRef]

180. Alfieri, M.; Berardo, N.; Redaelli, R.; Hidalgo, A. Carotenoid composition and heterotic effect in selected Italian maize germplasm. J. Cereal Sci. 2014, 59, 181-188. [CrossRef]

181. Britton, G.; Khachik, F. Carotenoids in Food. In Carotenoids_Volume 5: Nutrition and Health; Britton, G., Liaaen-Jensen, S., Pfander, H., Eds.; Birkhäuser: Basel, Switzerland; Boston, MA, USA; Berlin, Germany, 2009; pp. 45-66.

182. Rodriguez-Amaya, D. A Guide to Carotenoid Analysis in Foods; ILSI Press: Washington, DC, USA, 2001.

183. Alquezar, B.; Rodrigo, M.J.; Zacarías, L. Regulation of carotenoid biosynthesis during fruit maturation in the red-fleshed orange mutant Cara Cara. Phytochemistry 2008, 69, 1997-2007. [CrossRef]

184. Rodrigo, M.-J. Characterization of Pinalate, a novel Citrus sinensis mutant with a fruit-specific alteration that results in yellow pigmentation and decreased ABA content. J. Exp. Bot. 2003, 54, 727-738. [CrossRef]

185. Fray, R.G.; Grierson, D. Identification and genetic analysis of normal and mutant phytoene synthase genes of tomato by sequencing, complementation and co-suppression. Plant Mol. Biol. 1993, 22, 589-602. [CrossRef] [PubMed]

186. Ronen, G.; Cohen, M.; Zamir, D.; Hirschberg, J. Regulation of carotenoid biosynthesis during tomato fruit development, expression of the gene for lycopene epsilon-cyclase is down-regulated during ripening and is elevated in the mutant Delta. Plant J. 1999, 17, 341-351. [CrossRef]

187. Lu, S.; Eck, J.; van Zhou, X.; Lopez, A.B.; O’Halloran, D.M.; Cosman, K.M.; Conlin, B.J.; Dominick, J.; Paolillo, D.J.; Garvin, D.F.; et al. The Cauliflower or Gene Encodes a DnaJ Cysteine-Rich Domain-Containing Protein That Mediates High Levels of b-Carotene Accumulation. Plant Cell 2006, 18, 3594-3605. [CrossRef] [PubMed]

188. Ye, X.D.; Al Babili, S.; Kloti, A.; Zhang, J.; Lucca, P.; Beyer, P.; Potrykus, I. Engineering the provitamin A (beta-carotene) biosynthetic pathway into (carotenoid-free) rice endosperm. Science 2000, 287, 303-305. [CrossRef] [PubMed]

189. Meléndez-Martínez, A.J.; Fraser, P.D.; Bramley, P.M. Accumulation of health promoting phytochemicals in wild relatives of tomato and their contribution to in vitro antioxidant activity. Phytochemistry 2010, 71, 1104-1114. [CrossRef]

190. Rodriguez-Amaya, D.B.; Kimura, M. Harvest Plus Handbook for Carotenoid Analysis; International Food Policy Research Institute (IFPRI): Washington, DC, USA; International Center for Tropical Agriculture (CIAT): Cali, Colombia, 2004.

191. Sivakumar, D.; Jifon, J.; Soundy, P. Spectral quality of photo-selective shade nettings improves antioxidants and overall quality in selected fresh produce after postharvest. Food Rev. Int. 2017, 34, 290-307. [CrossRef]

192. Sakalauskaitè, J.; Viskelis, P.; Dambrauskienè, E.; Sakalauskienè, S.; Samuoliene, G.; Brazaitytè, A.; Duchovskis, P.; Urbonavičienė, D. The effects of different UV-B radiation intensities on morphological and biochemical characteristics in Ocimum basilicum $\mathrm{L}$. J. Sci. Food Agric. 2013, 93, 1266-1271. [CrossRef]

193. Poiroux-Gonord, F.; Bidel, L.P.R.; Fanciullino, A.L.; Gautier, H.; Lauri-Lopez, F.; Urban, L. Health benefits of vitamins and secondary metabolites of fruits and vegetables and prospects to increase their concentrations by agronomic approaches. J. Agric. Food Chem. 2010, 58, 12065-12082. [CrossRef]

194. Li, P.; Cheng, L. The shaded side of apple fruit becomes more sensitive to photoinhibition with fruit development. Physiol. Plant. 2008, 134, 282-292. [CrossRef]

195. Kimura, M.; Rodriguez-Amaya, D.B.; Yokoyama, S.M. Cultivar differences and geographic effects on the carotenoid composition and vitamin A value of papaya. Leb. Wissen Technol. 1991, 24, 415-418.

196. Mercadante, A.Z.; Rodriguez-Amaya, D.B. Effects of Ripening, Cultivar Differences, and Processing on the Carotenoid Composition of Mango. J. Agric. Food Chem. 1998, 46, 128-130. [CrossRef]

197. Mercadante, A.Z.; Rodriguez-Amaya, D.B. Carotenoid composition of a leafy vegetable in relation to some agricultural variables. J. Agric. Food Chem. 2002, 39, 1094-1097. [CrossRef]

198. Coyago-Cruz, E.; Corell, M.; Moriana, A.; Hernanz, D.; Benítez-González, A.M.; Stinco, C.M.; Meléndez-Martínez, A.J. Antioxidants (carotenoids and phenolics) profile of cherry tomatoes as influenced by deficit irrigation, ripening and cluster. Food Chem. 2018, 240, 870-878. [CrossRef] [PubMed]

199. Geetha, G.A. Changes in fruit quality and carotenoid profile in tomato (Solanum lycopersicon L.) genotypes under elevated temperature. J. Hortl. Sci. 2015, 10, 38-43.

200. Loladze, I.; Nolan, J.M.; Ziska, L.H.; Knobbe, A.R.; Loladze, I.; Knobbe, A.R. Carotenoids and Carbon Dioxide Rising Atmospheric CO2 Lowers Concentrations of Plant Carotenoids Essential to Human Health, A Meta-Analysis. Mol. Nutr. Food Res. 2019, 63, e1801047. [CrossRef] [PubMed]

201. Dzomeku, B.; Wald, J.; Wünsche, J.; Nohr, D.; Biesalski, H. Climate Change Enhanced Carotenoid Pro-Vitamin A Levels of Selected Plantain Cultivars. Plants 2020, 9, 541. [CrossRef] [PubMed]

202. Navarro, J.M.; Flores, P.; Garrido, C.; Martinez, V. Changes in the contents of antioxidant compounds in pepper fruits at different ripening stages, as affected by salinity. Food Chem. 2006, 96, 66-73. [CrossRef] 
203. Bang, H.; Leskovar, D.I.; Bender, D.A.; Crosby, K. Deficit irrigation impact on lycopene, soluble solids, firmness and yield of diploid and triploid watermelon in three distinct environments. J. Hortic. Sci. BioTechnol. 2004, 79, 885-890. [CrossRef]

204. Proietti, S.; Rouphael, Y.; Colla, G.; Cardarelli, M.; de Agazio, M.; Zacchini, M.; Rea, E.; Moscatello, S.; Battistelli, A. Fruit quality of mini-watermelon as affected by grafting and irrigation regimes. J. Sci. Food Agric. 2008, 88, 1107-1114. [CrossRef]

205. Sánchez-Rodríguez, E.; Leyva, R.; Constán-Aguilar, C.; Romero, L.; Ruiz, J.M. Grafting under water stress in tomato cherry, improving the fruit yield and quality Grafting under water stress in tomato cherry, improving the fruit yield and quality. Ann. Appl. Biol. 2012, 161, 302-312. [CrossRef]

206. Buendía, B.; Allende, A.; Nicolás, E.; Alarcón, J.J.; Gil, M. Effect of Regulated Deficit Irrigation and Crop Load on the Antioxidant Compounds of Peaches. J. Agric. Food Chem. 2008, 56, 3601-3608. [CrossRef] [PubMed]

207. Tian, S.-L.; Lu, B.-Y.; Gong, Z.-H.; Shah, S.N.M. Effects of drought stress on capsanthin during fruit development and ripening in pepper (Capsicum annuum L.). Agric. Water Manag. 2014, 137, 46-51. [CrossRef]

208. Flores, P.; Navarro, J.; Garrido, C.; Rubio-Asensio, J.S.; Martínez, V. Influence of Ca2+, K+ and NO3- fertilisation on nutritional quality of pepper. J. Sci. Food Agric. 2004, 84, 569-574. [CrossRef]

209. Seljåsen, R.; Kristensen, H.L.; Lauridsen, C.; Wyss, G.S.; Kretzschmar, U.; Birlouez-Aragone, I.; Kahl, J. Quality of carrots as affected by pre- and postharvest factors and processing. J. Sci. Food Agric. 2013, 93, 2611-2626. [CrossRef]

210. Dorais, M. Effect of cultural management on tomato fruit health qualities. Acta Hortic. 2007, 744, 279-294. [CrossRef]

211. Jones, R.B.B.; Stefanelli, D.; Tomkins, R.B.B. Pre-harvest and post-harvest factors affecting ascorbic acid and carotenoid content in fruits and vegetables. Acta Hortic. 2015, 1106, 31-41. [CrossRef]

212. Granado, F.; Olmedilla, B.; Blanco, I.; Rojas Hidalgo, E. Carotenoid composition in raw and cooked Spanish vegetables. J. Agric. Food Chem. 1992, 40, 2135-2140. [CrossRef]

213. Knockaert, G.; Pulissery, S.K.; Colle, I.; van Buggenhout, S.; Hendrickx, M.; van Loey, A. Lycopene degradation, isomerization and in vitro bioaccessibility in high pressure homogenized tomato puree containing oil, Effect of additional thermal and high pressure processing. Food Chem. 2012, 135, 1290-1297. [CrossRef]

214. Nguyen, M.; Francis, D.; Schwartz, S. Thermal isomerisation susceptibility of carotenoids in different tomato varieties. J. Sci. Food Agric. 2001, 81, 910-917. [CrossRef]

215. Meléndez-Martínez, A.J.; Vicario, I.M.; Heredia, F.J. Carotenoids, Color, and Ascorbic Acid Content of a Novel Frozen-Marketed Orange Juice. J. Agric. Food Chem. 2007, 55, 1347-1355. [CrossRef] [PubMed]

216. Moyano, M.J.; Meléndez-Martínez, A.J.; Alba, J.; Heredia, F.J. A comprehensive study on the colour of virgin olive oils and its relationship with their chlorophylls and carotenoids indexes (I), CIEXYZ non-uniform colour space. Food Res. Int. 2008, 41, 505-512. [CrossRef] 